NBER WORKING PAPER SERIES

\title{
SMOKE SIGNALS: ADOLESCENT SMOKING AND SCHOOL CONTINUATION
}

\author{
Philip J. Cook \\ Rebecca Hutchinson \\ Working Paper 12472 \\ http://www.nber.org/papers/w12472
}

\author{
NATIONAL BUREAU OF ECONOMIC RESEARCH \\ 1050 Massachusetts Avenue \\ Cambridge, MA 02138 \\ August 2006
}

We thank Marina Bianchi and the participants at the University of Cassino Workshop for helpful comments. Bob Malme and Sam Abzug provided first-rate research assistance. The views expressed herein are those of the author(s) and do not necessarily reflect the views of the National Bureau of Economic Research.

(C2006 by Philip J. Cook and Rebecca Hutchinson. All rights reserved. Short sections of text, not to exceed two paragraphs, may be quoted without explicit permission provided that full credit, including @ $)$ notice, is given to the source. 
Smoke Signals: Adolescent Smoking and School Continuation

Philip J. Cook and Rebecca Hutchinson

NBER Working Paper No. 12472

August 2006

JEL No. I12, I2

\begin{abstract}
This paper presents an exploratory analysis using NLSY97 data of the relationship between the likelihood of school continuation and the choices of whether to smoke or drink. We demonstrate that in the United States as of the late 1990s, smoking in 11th grade was a uniquely powerful predictor of whether the student finished high school, and if so whether the student matriculated in a four-year college. For economists the likely explanation for this empirical link would be based on interpersonal differences in time preference, but that account is called in question by our second finding -- that drinking does not predict school continuation. We speculate that the demand for tobacco by high school students is influenced by the signal conveyed by smoking (of being off track in school), one that is especially powerful for high-aptitude students. To further develop this view, we present estimates of the likelihood of smoking as a function of school commitment and other, more traditional variables. There are no direct implications from this analysis for whether smoking is in some sense a cause of school dropout. We offer some speculations on this matter in the conclusion.
\end{abstract}

Philip J. Cook

Terry Sanford Institute of Public Policy

Box 90245

Duke University

Durham, NC 27708

and NBER

pcook@duke.edu 


\section{A. Introduction}

Smoking initiation by adolescents has been analyzed by economists as a choice reflecting prices, tastes, and subjective evaluation of the long-term risks of addiction and disease. What is missing from this account is the fact that smoking is a social activity and subject to peer influence. Peers may serve as a source of information about why and how to smoke, and how to obtain cigarettes. Peers also serve as an audience, observing and evaluating others' behavior. That evaluation is mediated by the long association in popular culture between smoking and a variety of attributes prized by adolescents. Like choice of fashion in hair and clothing, body piercing, comportment, and so forth, smoking by adolescents connotes information about identity. Knowing that, the decision of whether to smoke is partly a decision of what identity to project.

Smoking has long been linked in popular culture to such attributes as autonomy, rejection of mainstream values, sophistication, and being "cool." These cultural links are no doubt strengthened for adolescents by the fact that smoking is illegal for those under 18 , banned by many schools, frowned on by adults, and known to be potentially harmful. While these attributes make smoking more attractive to many adolescents, it is also true that smoking sends a signal of being off track in school that would generally be perceived by peers as negative.

In particular, in this paper we demonstrate that in the United States as of the late 1990s, smoking in $11^{\text {th }}$ grade was a uniquely powerful predictor of whether the student finished high school, and if so whether the student matriculated in a four-year college. For economists the obvious explanation for this empirical link is interpersonal differences in time preference. Smoking offers immediate benefits (to those who enjoy it) with long 
delayed costs in the form of disease, disability, and early death. Dropping out of school also offers immediate benefits (for those who would rather have more leisure or earnings) with delayed costs in terms of limited career options. That smokers drop out early is then simply a reflection of their high rate of time discount. This explanation is satisfying because it is based on well-established concepts relating to time preference (Hoppe 2001; Menger [1871] 1976; Mises [1949] 1998; Böhm-Bawerk [1884-1921] 1959; Strigl 2001; Rothbard [2004] 1963). Time preference rates are deemed subjective and to differ among individuals (Smith 1988: 5). These differences have been identified as central to explaining the socioeconomic class structure (Banfield 1974) and explaining differences in criminal propensities (Banfield 1974; Banfield 1977; Wilson \& Herrnstein 1985).

What confuses this simple account is our finding that a parallel activity, drinking, is not predictive of school dropout - despite the fact that its temporal payoff is quite similar to smoking. If adolescent decisions about health-related behaviors are generally guided by concern for the future, then why doesn't adolescent drinking follow the same pattern as smoking? That anomalous finding opens the door to other kinds of explanation, including social status concerns. (While economists may be uncomfortable with this line of explanation, social psychologists would accept status sensitivity as a fundamental of human nature.) When it comes to social status, both the costs and benefits of smoking are immediate but differ among individuals according to whether they would otherwise be perceived by peers as being on track to college, and whether they are in fact on track. We suggest that the decision to smoke is being driven in part by the fact that youths are aware of the messages it conveys to their peers. The smoking signal conveys more information for high-aptitude youths than those with low aptitude, 
and hence carries a greater social cost for the former. It turns out that both aptitude and commitment to school appear to influence smoking decisions.

In what follows, we describe the data set, present results demonstrating the predictive power of smoking and drinking, and then estimate a demand function for smoking by high-school juniors that includes whether they are destined to graduate and go on to college. We offer an explanation for the empirical findings that rests on smoking as one signal of being unlikely to continue in school, the power of which is conditioned on aptitude.

There are no direct implications from this analysis for whether smoking is in some sense a cause of school dropout. We offer some speculations on this matter in the conclusion.

\section{B. The Data}

Our data source is the 1997 National Longitudinal Survey of Youth (NLSY), sponsored by the Bureau of Labor Statistics of the US Department of Labor. The sample of 8,984 individuals surveyed is representative of the US population in 1997 that was born between 1980 and 1984 (Center for Human Resource Research 2002). Data were gathered through hour-long interviews with the participants and questionnaires completed by the parents in that year. Additional data have been collected from the participants every year since; the Labor Department has released these data from the six waves through 2002. 
The NLSY data include detailed information on respondents' demographic characteristics, family, work, criminal activities, and health status. Of particular relevance to our work are the items on drinking, smoking, and schooling.

Our estimates are based on a sub-sample of 3,915 NLSY respondents who were juniors in high school in 1997, 1998, or 1999. (We excluded those who were relatively old for this grade, and in particular those who were over 18.) Key outcome measures include whether the respondent graduated from high school the year following junior year, and whether the respondent matriculated in a four-year college or university thereafter.

Definitions and summary statistics for all variables used in the analysis are presented in Table A1.

C. Smoking as a Predictor of School Continuation

Respondents who said that they had smoked at least one cigarette in the previous 30 days were designated "smokers." Those who had at least one drink of alcohol in the previous 30 days were designated "drinkers," and those who admitted to having 5 or more drinks on at least four occasions in that period were designated "frequent binge drinkers."

Another key variable in our analysis is the respondent's score on the math component of the Armed Services Vocational Aptitude Battery (ASVAB). This test was given to most of the NLSY respondents in 1997. Together with modules testing other aptitudes, it was developed by the US military to guide placement of new recruits into 
alternative specialties. It is also valid as a predictor of school achievement (Roberts, et al. 2000).

Tables 1 and 2 compare smokers and non-smokers for various subgroups of respondents with respect to high-school graduation rates, and college matriculation rates. For the entire sample, the high school on-time graduation rate for males is $60 \%$ for smokers and $75 \%$ for nonsmokers; the college matriculation rate is $12 \%$ for smokers and $30 \%$ for nonsmokers, a more than two-to-one difference. For females, the high school graduation rate is $71 \%$ for smokers and $80 \%$ for nonsmokers; the college matriculation rates are $21 \%$ and $37 \% .^{1}$

The results presented in these tables make clear that the "smoking signal" applies not only to the population of high-school juniors as a whole, but also to each of several subgroups. Non-smokers are more likely than smokers to continue their education: for respondents with low ASVAB as well as those with high; for youths with mothers or fathers who are high school dropouts, as well as those who are college graduates; and for each of three groups defined by race (black, Hispanic, and all others). These results are depicted in Figure 1 as well.

We refined this analysis by running multivariate logit regressions for males and females. These regressions analyze the effect of smoking on the odds of high school graduation and college matriculation controlling for demographic and family circumstances. Full results are reported in Table A2. Partial results of two specifications are reported in Table 3: the first specification includes the smoker dummy variable, but nothing on drinking, while the second specification adds two drinking indicators -- an indicator of whether the respondent is a drinker and an indicator of whether the

\footnotetext{
${ }^{1}$ These results are based on counts of respondents, and do not employ the sample weights.
} 
respondent is a frequent binger. Each coefficient reported in the table includes the zstatistic, the ratio of the estimated coefficient and standard error, which in the limit has a normal distribution.

The logit regressions demonstrate that smoking is strongly (negatively) predictive of high school graduation and especially college matriculation for both males and females even after adjusting for family structure, socioeconomic status, academic ability and other characteristics of the respondent. On the other hand, drinkers have about the same chances as nondrinkers when smoking is held constant. The exception is the small group of females who are frequent bingers, who have a reduced likelihood of school continuation.

The predictive importance of smoking is suggested by the fact that the estimated effect on the log odds of college matriculation of smoking is larger than the effect of having a father who is a dropout rather than a college graduate (other things equal).

While smoking status is a strong predictor of school continuation, the most powerful predictor is the math ASVAB score. The coefficient estimates and z statistic are reported in Table 3. As an example, consider the estimated effect of moving up by one standard deviation on ASVAB score. For males, that would increase the odds of graduating from high school by a factor of 1.7, and the odds of matriculating by a factor of 3.4. For females, moving up one standard deviation on ASVAB would increase the odds of graduating from high school by a factor of 2.0, and increase the odds of matriculating by $2.8 .^{2}$

\footnotetext{
${ }^{2}$ We experimented a bit with the sample and specification. The estimated effect of ASVAB is almost identical in baseline equations (not shown) that have no drinking or smoking variables. Table A3 presents the results of the same regressions run for the sub-sample of respondents who are white or "other" races neither black nor Hispanic. Isolating this group is of interest because there does appear to be a strong
} 
Since the logit specification is multiplicative, the absolute effect of smoking on the odds of school continuation increases with ability. That fact is illustrated by Figure 3, which depicts the effect of being a smoker in junior year on the probability of college matriculation the following year over a wide range of ASVAB scores (four standard deviations). At two SDs below the mean the likelihood of college matriculation is very small for both smokers and nonsmokers. Even though smoking is a negative signal, it is of little consequence given low ability. Above the mean the smoking gap becomes wide.

D. Alternative perspectives on adolescent smoking

Given that smoking is negatively linked to school continuation among $11^{\text {th }}$ graders, we expect that $11^{\text {th }}$ graders will take that fact into account when deciding whether to smoke. Which of the following is important in a 16- or 17-year-old deciding whether to smoke?:

- Tastes: the intrinsic pleasure of inhaling smoke and blowing it out again

- Price and availability of cigarettes and related commodities

- Concern about the possibility of becoming habituated to tobacco and someday suffering adverse health consequences

- Assessment of what peers and adults will think The traditional economics literature has focused on the first three concerns. Tastes and price are considerations for any commodity. The fact that smoking has health consequences suggests that the decision to smoke is part of the portfolio of investments

"race" effect in smoking and drinking. As it turns out, however, the prediction equations are quite similar with respect to the key coefficients. We also experimented with adding an interaction term (ASVAB * Smoking) to the prediction equations, but none of the coefficient estimates on this interaction term had a statistically discernible effect. (Most of the z-statistics were less than one.) 
and disinvestments in "health capital" (Grossman 1972), and for that reason preferences concerning time and risk also become important. Because smoking is addictive, there are an additional set of delayed consequences associated with smoking including tolerance and habituation; these consequences may also influence current decisions (Becker \& Murphy 1988; Chaloupka 1991; Becker, Grossman \& Murphy 1991). Some evidence from this analysis points to a conclusion that youthful smoking decisions reflect a higher rate of time discount - greater "myopia" -- than for adults (Chaloupka 1991).

A series of studies by Joni Hersch and her associates have produced evidence that adult smokers as a group tend to be risk takers, careless of their health and life in domains other than smoking (Hersch \& Viscusi 1990; Hersch \& Pickton 1995; Hersch \& Viscusi 1998). "In terms of the level of risk, smokers are less likely to perform preventive health activities such as seatbelt use, flossing, and checking their blood pressure. They choose riskier jobs, are more likely to be injured on their jobs controlling for objective measures of risk, are more likely to have an accident at home, and are more likely to have an accident overall (Hersch \& Viscusi 1998).”

Following this line of logic, an explanation for the negative link between smoking and school continuation among adolescents is that both are influenced by the time preferences of the individuals - other things equal, youths who are more present-oriented will be more likely than their peers to smoke (because they discount long-term negative consequences) and more likely to end their schooling early.

But if youths care about the opinions of their peers, then the logic is not so clear. For $11^{\text {th }}$ graders, smoking, as demonstrated in the previous section, is a signal of being off track and unsuccessful in the school domain. That message may cause smokers to 
lose standing with peers, most of whom aspire to graduate from high school and obtain a college education (Cook \& Ludwig 1997). That loss of standing will be an immediate cost and hence of particular salience to present-oriented youths. On the other hand, the cost of being identified as "off track" is less for those who are in fact off track, than for those who are. For one thing, classmates will probably have reason to suspect the truth already from other behaviors, and in any event it will soon be revealed when the individual does terminate schooling.

Part of the "signaling" story, then, is that those who are disaffected from school and inclined to terminate will find smoking more attractive than those who intend to continue, because the "off track" identity signal is less costly in terms of peer standing than for those who are on track. But there is more to the story, a positive benefit as well as a reduced cost. In popular culture, not to mention tobacco advertising, smoking has long been associated with being "cool", independent, sophisticated, and rebellious - all values that are prized by adolescents, and which may get them off track in their school careers (Abaum, et al. 2002; Aloise-Young \& Hennigan 1996; Luke, et al. 2001; Kobus 2003). Many teens valued the smoking image enough to wear promotional items from the cigarette companies when such items were permitted (Wakefield, et al. 2003). But while these associations are generally attractive to adolescents, they are disinclined to project an image or claim an identity that is too far out of line with reality (McKennell \& Bynner 1969; Chassin, et al. 1981; Grube, et al. 1984; Chassin, et al. 1985; Burton, et al. 1989). The psychologists have established that identification with the images associated with smoking is a strong predictor of becoming a smoker (Aloise-Young \& Hennigan 1996). 
In sum, those youths who smoke and thereby assume the image associated with being a smoker incur the reputational costs of being considered off track and the benefits of being associated with an activity that connotes cool, sophistication, and rebelliousness. The cost is less for those who are genuinely off track, and the image of cool detachment or rebellion is likely to be more appealing and successful for those who genuinely identify with it. ${ }^{3}$

Finally, there is good reason to believe that the reputational costs of smoking are less for students of low ability than for those who are above average, simply because, as we have seen, the "smoking gap" in the likelihood of school success is so much larger for high-ability students. ${ }^{4}$

Bringing together these conceptual strands, we propose that the smoking decision by adolescents is made in a social context where being a smoker conveys a signal about their personality ("cool") and their likely success in school (questionable). The smoking decision is made in circumstances where their peers may observe other signals of schooling success; in particular their academic ability is somewhat visible, and for that

\footnotetext{
${ }^{3}$ This story may be developed somewhat differently based on Akerlof and Kranton's theory of identity and economic behavior (Akerlof \& Kranton 2000; Akerlof \& Kranton 2002). They note that the school social scene is highly structured into groups or social categories, such as the leading crowd, nerds, and burnouts. Students have certain attributes that determine the utility payoffs from membership in each group, and then select one accordingly. Complying with the behavioral norms of the group has an immediate payoff from identification with that group even when the behavior conflicts with other interests of the individual. If smoking is a valued behavior among the burnouts, then those who select the burnout category for other reasons (a lack of interest in or ability for schoolwork) may begin smoking.
}

\footnotetext{
${ }^{4}$ An interesting possibility is that the members of the student body who are most clearly destined for success will choose to smoke as a "counter signal" that separates them from the middle range of on-track students. In an article with the perfect title "Too cool for school?," Feltovich, Harbaugh and To note that "high types sometimes avoid the signals that should separate them from lower types, while intermediate types often appear the most anxious to send the 'right' signals. The nouveau riche flaunt their wealth, but the old rich scorn such gauche displays....Mediocre students answer a teacher's easy questions, but the best students are embarrassed to prove their knowledge of trivial points (Feltovich, Harbaugh \& To 2002: 631)." This effort by the elite to separate from the middle is possible, they note, in a circumstance where there are other signals of success.
} 
reason the negative connotations of the signal - its cost -- are inversely related to academic ability. The cost of the signal also depends on whether they are in fact off track; those who are off track and have embraced an oppositional identity will find it less costly (or perhaps even rewarding) to signal that identity.

To translate this framework into symbols, we have:

$\mathrm{V}=$ student's intrinsic taste for smoking

$\mathrm{C}=$ social cost of smoking to the student (positive or negative)

$\mathrm{A}=$ aptitude

$\mathrm{P}=$ extent to which the student is "on track" (committed to continuing school)

$\mathrm{F}=$ financial cost of smoking

$\mathrm{H}=$ current valuation of smoking cost to present and future health

$r=$ rate of time discount

$\mathrm{s}=$ the strength of the statistical link between smoking and likelihood of school continuation $\mathrm{V}=\mathrm{V}(\mathrm{r})$, with $\mathrm{V}^{\prime}>0$ (higher rate of time discount enhances valuation of smoking) $\mathrm{C}=\mathrm{C}(\mathrm{A}, \mathrm{P}: \mathrm{s})$, increasing in both $\mathrm{A}$ and $\mathrm{P}$ conditional on a negative association $\mathrm{s}$ $\mathrm{P}=\mathrm{P}(\mathrm{r})$, with $\mathrm{P}^{\prime}<0$ (commitment to school declines as discount rate increases) $\mathrm{H}=\mathrm{H}(\mathrm{r})$, with $\mathrm{H}^{\prime}<0$ (concern about health consequences declines as discount rate increases)

The student will choose to smoke if

$\mathrm{V}>\mathrm{C}[\mathrm{A}, \mathrm{P}(\mathrm{r}): \mathrm{s}]+\mathrm{F}+\mathrm{H}(\mathrm{r})$ 
Assuming that taste for smoking $\mathrm{V}$ is distributed in the student population independently of the other variables, then the likelihood a particular student will choose to smoke depends on aptitude (negatively) and commitment to school (negatively) to an extent that is influenced by the strength of the smoking signal; the likelihood of smoking is positively related to rate of time discount, both because of the salience of future health effects, and the commitment to continuing in school.

\section{E. Empirical determinants of smoking and drinking}

We estimated standard equations for smoking participation among the $11^{\text {th }}$ graders in the NLSY sample, and report partial results in Table 4 (and complete results in Table A4). The unusual feature of the specifications is that they include indicators of subsequent events, namely whether the respondent graduated from high school the following year and whether he matriculated in a four-year college. These indicators are intended as proxies for the extent to which the respondent is on track or off in $11^{\text {th }}$ grade. One alternative is to utilize contemporaneous reports from the respondent about how far she expects to go in school (Gruber \& Zinman 2001), but such reports are not available in the NLSY.

The main results come as no surprise given the previous findings. Those who are on track to graduating from high school are less likely to smoke, and those who are on track to matriculating in a 4-year college much less likely to smoke, in comparison to their classmates. That is true despite the fact that the specifications control for a number of variables which may influence smoking, including socioeconomic status, race, family 
characteristics, and cigarette prices. We also find that ability, as measured by ASVAB, has a strong, independent negative effect on the likelihood of smoking, as suggested by the signaling story.

The respondent's report on the prevalence of smoking among her peers has a strong positive association with whether or not the respondent smokes. ${ }^{5}$ This may reflect peer influence, or it may be an artifact of the well known pattern that smokers choose to associate with other smokers and may get a biased impression of their overall prevalence as a result. In any event, it is interesting to note that controlling for peer smoking has little effect on the coefficients for high school graduation and college matriculation.

For drinking, the influence of being on track is less consistently evident, as shown in Table 5. High school graduation is statistically irrelevant, while college matriculation has a modest negative effect on the likelihood of drinking. ASVAB has a weak effect. Interestingly, the percentage of peers who smoke is quite closely linked to the drinking decision.

These results on smoking and drinking are compatible with both the "time discount" story and the "social cost" story for the smoking decision - and indeed, we believe they both have some validity. The fact that ability has a strong independent effect on smoking (even after controlling for whether the student is on track) is better captured by the "signaling" story than the "rate of time discount" story.

The fact that being on track to high school graduation has no effect on whether the $11^{\text {th }}$ grade respondent drinks may also be relevant in distinguishing between the two

\footnotetext{
${ }^{5}$ For the peer smoking question, respondents are shown a card that has 5 choices, and told to choose one: 1. Almost none (less than 10\%; 2. About 25\% 3. About half (50\%); 4. About 75\% 5.Almost all (more than $90 \%)$.
} 
stories. Drinking is an activity that has much in common with smoking for an $11^{\text {th }}$ grader - it is illegal, frowned on by authorities, and has the potential to do harm over time through addiction and direct risks to health and safety. (Recent research suggests that drinking can do permanent damage to the developing brain of an adolescent.) It would seem, then, that if time preference influenced the likelihood of smoking, it should also influence the likelihood of drinking. The lack of a finding in this respect adds credence to the second "signaling" perspective on smoking.

\section{F. Concluding thoughts}

Our analysis has documented the strength of smoking as a signal of being off track for juniors in high school. That signal conveys much more information for youths who are likely to graduate and go on to college, than for those who are likely to exit early from schooling. If we make the plausible assumption that adolescents care about what their peers believe about them, and that most youths do not want to be viewed by their peers as "losers," then smoking has a social cost. We have demonstrated that that cost is lower for lower-ability students, and is likely to be lower for those who are genuinely disaffected and off track. These observations provide an explanation for observed patterns of smoking among $11^{\text {th }}$ graders, including the strong link to ability and school continuation. That explanation should not be viewed as a rival to the traditional "time horizon" explanation in economics. "Peer reputation" and "time horizon" are both plausible explanations. Our point is that the "time horizon" explanation is not complete, and in particular does not explain the relationship between smoking and ability. 
Our analysis does not speak to the question of whether smoking has a causal effect on schooling. For example, we can't say whether an increase in the tobacco tax would increase college matriculation rates. However, if peer effects are important to the decision of whether to smoke, and the social processes described here result in a tight link between smoking and oppositional culture, then it is not implausible that a youth with a strong taste for tobacco might hang out with "bad company" just for companionship in his smoking. That association in turn may push him off track with respect to schooling.

Finally, we note that our results on smoking and schooling may not apply to other times and places. To the extent that smoking patterns are influenced by peer-group concerns, they are self-perpetuating, with the possibility of several stable equilibria. It would be interesting to replicate this study using U.S. data from an earlier era, say the 1950s, when smoking among adults was much more prevalent and less closely linked to education than now, or to analyze smoking and schooling patterns for other wealthy nations where smoking may convey a more ambiguous social signal than in the United States today. 
References

Abaum, G., Baker, K.G., Hozier, G.C., Jr. and Rogers, R.D., "Smoking Behavior, Information Sources, and Consumption Values of Teenagers: Implications for Public Policy and Other Intervention Faillures," 2002.

Akerlof, George A. and Kranton, Rachel E., "Economics and Identity," Quarterly Journal of Economics, 105(3), 2000, 715-753.

Akerlof, George A. and Kranton, Rachel E., "Identity and Schooling: Some Lessons for the Economics of Education," Journal of Economic Literature, 40(4), 2002, 1167-1201.

Aloise-Young, P.A. and Hennigan, K.M., "Self-Image, the Smoker Stereotype and Cigarette Smoking: Developmental Patterns Fro Fifth to Eighth Grade," Journal of Adolescence, 1996, 163-177.

Banfield, Edward, "Present-Orientedness and Crime," in Randy E. Barnett and John Hagel, eds., Assessing the Criminal: Restitution, Retribution, and the Legal Process, Cambridge: Ballinger, 1977.

Banfield, Edward, The Unheavenly City Revisited, Bsoton: Little, Brown and Company, 1974.

Becker, Gary S., Grossman, Michael and Murphy, Kevin M., "Rational Addiction and the Effect of Price on Consumption," American Economic Review, 81(2), 1991, 237-241.

Becker, Gary S. and Murphy, Kevin M., "A Theory Of Rational Addiction," Journal of Political Economy, 96(4), 1988, 675-700.

Böhm-Bawerk, Eugen von, Capital and Interest, Kapital und Kapitalzins, South Holland, Illinois: Libertarian Press, [1884-1921] 1959.

Burton, D., et al., "ImAge Attribution and Smoking Intentions Among Seventh Grade St," Journal of Applied Social Psychology, 19, 1989, 656-664.

Center for Human Resource Research, Ohio State University, NLSY97 User's Guide, Columbus, Ohio: Ohio State University, 2002.

Chaloupka, Frank, "Rational Addictive Behavior and Cigarette Smoking," Journal of Political Economy, 99(4), 1991, 722-742.

Chassin, L., et al., "Psychosocial Correlates of Adolescent Smokless Tobacco Use," Addictive Behaviors, 10, 1985, 431-435.

Chassin, L., et al., "Self-Images and Smoking in Adolescence," Personality and Social Psychology Bulletin, 7, 1981, 670-676.

Cook, Philip J. and Ludwig, Jens, "Weighing the Burden of 'Acting White'; Are There Race Differences in Attitudes Towards Education?" Journal of Policy Analysis and Management, 16(2), 1997, 256-278.

Feltovich, Nick, Harbaugh, Richmond and To, Ted, "To Cool for School? Signalling and Countersignalling," RAND Journal of Economics, 33(4), 2002, 630-649.

Grossman, Michael, "On the Concept of Health Capital and the Demand for Health," Journal of Political Economy, 80, 1972, 223-255.

Grube, J.W., Weir, I.L., Getzlaf, S. and Rokeach, M., "Own Value System, Value Images and Cigarette Smoking," Personality and Social Psychology Bulletin, 10, 1984, 306-313. 
Gruber, Jonathan and Zinman, Jonathan, "Youth Smoking in the United States:Evidence and Implications," in Jonathan Gruber, ed., Risky Behavior Among Youths: An Economic Analysis, Chicago: University of chicago Press, 2001, 69-120.

Hersch, Joni and Pickton, T.S., "Risk-Taking Activities and Heterogeneity of Job-Risk Tradeoffs," Journal of Risk and Uncertainty, 11(3), 1995, 205-217.

Hersch, Joni and Viscusi, W. Kip, "Cigarette Smoking, Seatbelt Use, and Differences in Wage-Risk Tradeoffs," Journal of Human Resources, 25(2), 1990, 202-227.

Hersch, Joni and Viscusi, W. Kip, "Smoking and Other Risky Behaviors," Journal of Drug Issues, 28(3), 1998, 645-661.

Hoppe, Hans-Hermann, Democracy-the God That Failed, New Brunswick, NJ: Transaction Publishers, 2001.

Kobus, Kimberly, "Peers and Adolescent Smoking," Addiction, 98 (Suppl 1), 2003, 37 55.

Luke, D., et al., "Teen's Images of Smoking and Smokers," Public Health Reports, 116, 2001, 194-202.

McKennell, A.C. and Bynner, J.M., "Self Images and Smoking Behavior Among School Boys," British Journal of Educational Psychology, 39, 1969, 27-39.

Menger, Carl, Principles of Economics, Grundsätze der Volkswirtschaftslehre, New York: New York University Press, [1871] 1976.

Mises, Ludwig von, Human Action: A Treatise on Economics 5th Ed., Auburn: Ludwig von Mises Institute, [1949] 1998.

Roberts, Richard D., et al., "The Armed Services Vocational Aptitude Battery," Learning and Individual Differences, 12(1), 2000, 81-103.

Rothbard, Marray N., Man, Economy, and State (2nd Ed.), Auburn, MI: Ludwig von Mises Institute, [2004] 1963.

Smith, T. Alexander, Time and Public Policy, Knoxville: University of Tennessee Press, 1988.

Strigl, Richard von, Capital and Production, Auburn, MI: Ludwig von Mises Institute, 2001.

Wakefield, M., Flay, Brian R., Nichter, M. and Giovino, G., "Role of the Media in Influencing Trajectories of Youth Smoking," Addiction, 98(Suppl 1), 2003, 79103.

Wilson, James Q. and Herrnstein, Richard J, Crime and Human Nature, New York:

Simon and Schuster, 1985. 
Table 1

A. Males

\begin{tabular}{|c|c|c|}
\hline \multicolumn{3}{|c|}{$\begin{array}{l}\text { Percentage of Male Youth who Enrolled in a Four-Year College } \\
\text { in the Year Immediately Following High School Graduation } \\
\text { (number in parentheses indicates total number of smokers or non-smokers) }\end{array}$} \\
\hline & $\begin{array}{c}\text { Smoker during Junior Year } \\
\text { of High School }\end{array}$ & $\begin{array}{c}\text { Non-Smoker during Junior } \\
\text { Year of High School }\end{array}$ \\
\hline \multicolumn{3}{|l|}{ By ASVAB Math } \\
\hline $\begin{array}{l}\text { Scored Below Median } \\
(1.03)\end{array}$ & $\begin{array}{l}3.0 \% \\
(199)\end{array}$ & $\begin{array}{l}11.3 \% \\
(592)\end{array}$ \\
\hline $\begin{array}{l}\text { Scored At or Above } \\
\text { Median }(1.03)\end{array}$ & $\begin{array}{c}26.1 \% \\
(138)\end{array}$ & $\begin{array}{l}44.2 \% \\
(651)\end{array}$ \\
\hline \multicolumn{3}{|l|}{ Mother's Education Level } \\
\hline $\begin{array}{l}\text { Mom Did Not } \\
\text { Complete High School }\end{array}$ & $\begin{array}{l}1.4 \% \\
(71)\end{array}$ & $\begin{array}{l}7.8 \% \\
(256)\end{array}$ \\
\hline $\begin{array}{l}\text { Mom Completed } \\
\text { High School }\end{array}$ & $\begin{array}{l}6.1 \% \\
(131)\end{array}$ & $\begin{array}{l}21.2 \% \\
(524)\end{array}$ \\
\hline $\begin{array}{l}\text { Mom Completed } \\
\text { High School } \\
\text { \& Some College }\end{array}$ & $\begin{array}{l}12.5 \% \\
(104)\end{array}$ & $\begin{array}{l}31.0 \% \\
(329)\end{array}$ \\
\hline $\begin{array}{l}\text { Mom Completed } \\
\text { College }\end{array}$ & $\begin{array}{c}32.3 \% \\
(62)\end{array}$ & $\begin{array}{l}54.2 \% \\
(286) \\
\end{array}$ \\
\hline \multicolumn{3}{|l|}{$\begin{array}{l}\text { By Father's Education } \\
\text { Level }\end{array}$} \\
\hline $\begin{array}{l}\text { Dad Did Not } \\
\text { Complete High School }\end{array}$ & $\begin{array}{l}3.6 \% \\
(56)\end{array}$ & $\begin{array}{l}13.3 \% \\
(181)\end{array}$ \\
\hline $\begin{array}{l}\text { Dad Completed } \\
\text { High School }\end{array}$ & $\begin{array}{l}3.1 \% \\
(97)\end{array}$ & $\begin{array}{l}18.4 \% \\
(337)\end{array}$ \\
\hline $\begin{array}{l}\text { Dad Completed } \\
\text { High School } \\
\& \text { Some College }\end{array}$ & $\begin{array}{l}14.5 \% \\
(69)\end{array}$ & $\begin{array}{l}31.3 \% \\
(243)\end{array}$ \\
\hline Dad Completed College & $\begin{array}{c}36.1 \% \\
(61)\end{array}$ & $\begin{array}{l}55.0 \% \\
(300)\end{array}$ \\
\hline \multicolumn{3}{|l|}{ By Ethnicity } \\
\hline Black & $\begin{array}{c}6.7 \% \\
(60) \\
\end{array}$ & $\begin{array}{l}20.2 \% \\
(392) \\
\end{array}$ \\
\hline Hispanic & $\begin{array}{l}2.8 \% \\
(72)\end{array}$ & $\begin{array}{l}13.0 \% \\
(322)\end{array}$ \\
\hline Other & $\begin{array}{l}13.8 \% \\
(276)\end{array}$ & $\begin{array}{l}35.1 \% \\
(823)\end{array}$ \\
\hline \multicolumn{3}{|c|}{ ***Excludes Missing Observations } \\
\hline \multicolumn{3}{|c|}{$\begin{array}{l}\text { Source: NLSY97; limited to those respondents who were juniors in high school in 1997, } \\
\text { 1998, or } 1999 .\end{array}$} \\
\hline
\end{tabular}


B. Females

\begin{tabular}{|c|c|c|}
\hline \multicolumn{3}{|c|}{$\begin{array}{l}\text { Percentage of Female Youth who Enrolled in a Four-Year College } \\
\text { in the Year Immediately Following High School Graduation } \\
\text { (number in parentheses indicates total number of smokers or non-smokers) }\end{array}$} \\
\hline & $\begin{array}{l}\text { Smoker during Junior Year } \\
\text { of High School }\end{array}$ & $\begin{array}{l}\text { Non-Smoker during Junior } \\
\text { Year of High School }\end{array}$ \\
\hline \multicolumn{3}{|l|}{ By ASVAB Math } \\
\hline $\begin{array}{l}\text { Scored Below Median } \\
(2.68)\end{array}$ & $\begin{array}{l}8.6 \% \\
(209)\end{array}$ & $\begin{array}{l}17.7 \% \\
(600)\end{array}$ \\
\hline $\begin{array}{l}\text { Scored At or Above } \\
\text { Median (2.68) }\end{array}$ & $\begin{array}{l}36.8 \% \\
(163)\end{array}$ & $\begin{array}{l}53.0 \% \\
(647)\end{array}$ \\
\hline \multicolumn{3}{|l|}{ Mother's Education Level } \\
\hline $\begin{array}{l}\text { Mom Did Not } \\
\text { Complete High School }\end{array}$ & $\begin{array}{l}4.3 \% \\
(70)\end{array}$ & $\begin{array}{l}16.6 \% \\
(271)\end{array}$ \\
\hline $\begin{array}{l}\text { Mom Completed } \\
\text { High School }\end{array}$ & $\begin{array}{l}13.4 \% \\
(134)\end{array}$ & $\begin{array}{l}27.8 \% \\
(507)\end{array}$ \\
\hline $\begin{array}{l}\text { Mom Completed } \\
\text { High School } \\
\& \text { Some College }\end{array}$ & $\begin{array}{c}23.6 \% \\
(127)\end{array}$ & $\begin{array}{l}35.0 \% \\
(329)\end{array}$ \\
\hline $\begin{array}{l}\text { Mom Completed } \\
\text { College }\end{array}$ & $\begin{array}{l}41.4 \% \\
(58)\end{array}$ & $\begin{array}{l}63.9 \% \\
(291)\end{array}$ \\
\hline \multicolumn{3}{|l|}{$\begin{array}{l}\text { By Father's Education } \\
\text { Level }\end{array}$} \\
\hline $\begin{array}{l}\text { Dad Did Not } \\
\text { Complete High School }\end{array}$ & $\begin{array}{c}10.5 \% \\
(38)\end{array}$ & $\begin{array}{l}18.4 \% \\
(196)\end{array}$ \\
\hline $\begin{array}{l}\text { Dad Completed } \\
\text { High School }\end{array}$ & $\begin{array}{l}16.2 \% \\
(105)\end{array}$ & $\begin{array}{l}35.0 \% \\
(317)\end{array}$ \\
\hline $\begin{array}{l}\text { Dad Completed } \\
\text { High School } \\
\& \text { Some College }\end{array}$ & $\begin{array}{c}25.0 \% \\
(76)\end{array}$ & $\begin{array}{c}43.5 \% \\
(200)\end{array}$ \\
\hline Dad Completed College & $\begin{array}{l}34.4 \% \\
(64)\end{array}$ & $\begin{array}{l}59.0 \% \\
(285)\end{array}$ \\
\hline \multicolumn{3}{|l|}{ By Ethnicity } \\
\hline Black & $\begin{array}{l}14.6 \% \\
(55)\end{array}$ & $\begin{array}{l}30.5 \% \\
(440)\end{array}$ \\
\hline Hispanic & $\begin{array}{l}13.9 \% \\
(65)\end{array}$ & $\begin{array}{l}18.3 \% \\
(333)\end{array}$ \\
\hline Other & $\begin{array}{l}22.0 \% \\
(318)\end{array}$ & $\begin{array}{l}42.4 \% \\
(759)\end{array}$ \\
\hline \multicolumn{3}{|c|}{ ***Excludes Missing Observations } \\
\hline \multicolumn{3}{|c|}{$\begin{array}{l}\text { Source: NLSY97; limited to those respondents who were juniors in high school in 1997, } \\
\text { 1998, or } 1999 \text {. }\end{array}$} \\
\hline \multicolumn{3}{|c|}{$\begin{array}{l}\text { Smoker is defined to be those respondents who had at least one cigarette in the } 30 \text { days } \\
\text { preceding the respondent's interview. }\end{array}$} \\
\hline
\end{tabular}


Table 2

A. Males

\begin{tabular}{|c|c|c|}
\hline \multicolumn{3}{|c|}{$\begin{array}{l}\text { Percentage of Male Youth who Graduated High School by Age } 19 \\
\text { (number in parentheses indicates total number of smokers or non-smokers) }\end{array}$} \\
\hline & $\begin{array}{l}\text { Smoker during Junior Year } \\
\text { of High School }\end{array}$ & $\begin{array}{l}\text { Non-Smoker during Junior } \\
\text { Year of High School }\end{array}$ \\
\hline \multicolumn{3}{|l|}{ By ASVAB Math } \\
\hline $\begin{array}{l}\text { Scored Below Median } \\
(1.03)\end{array}$ & $\begin{array}{c}48.7 \% \\
(199)\end{array}$ & $\begin{array}{l}62.3 \% \\
(592)\end{array}$ \\
\hline $\begin{array}{l}\text { Scored At or Above } \\
\text { Median (1.03) }\end{array}$ & $\begin{array}{c}74.6 \% \\
(138)\end{array}$ & $\begin{array}{l}85.3 \% \\
(651)\end{array}$ \\
\hline \multicolumn{3}{|l|}{ Mother's Education Level } \\
\hline $\begin{array}{l}\text { Mom Did Not } \\
\text { Complete High School }\end{array}$ & $\begin{array}{c}42.3 \% \\
(71)\end{array}$ & $\begin{array}{l}58.2 \% \\
(256) \\
\end{array}$ \\
\hline $\begin{array}{l}\text { Mom Completed } \\
\text { High School }\end{array}$ & $\begin{array}{l}55.7 \% \\
(131) \\
\end{array}$ & $\begin{array}{l}70.8 \% \\
(524)\end{array}$ \\
\hline $\begin{array}{l}\text { Mom Completed } \\
\text { High School } \\
\text { \& Some College }\end{array}$ & $\begin{array}{l}59.6 \% \\
(104)\end{array}$ & $\begin{array}{l}76.0 \% \\
(329)\end{array}$ \\
\hline $\begin{array}{l}\text { Mom Completed } \\
\text { College }\end{array}$ & $\begin{array}{c}77.4 \% \\
(62) \\
\end{array}$ & $\begin{array}{l}85.3 \% \\
(286) \\
\end{array}$ \\
\hline \multicolumn{3}{|l|}{$\begin{array}{l}\text { By Father's Education } \\
\text { Level }\end{array}$} \\
\hline $\begin{array}{l}\text { Dad Did Not } \\
\text { Complete High School }\end{array}$ & $\begin{array}{c}39.3 \% \\
(56)\end{array}$ & $\begin{array}{l}66.9 \% \\
(181) \\
\end{array}$ \\
\hline $\begin{array}{l}\text { Dad Completed } \\
\text { High School }\end{array}$ & $\begin{array}{c}64.9 \% \\
(97) \\
\end{array}$ & $\begin{array}{l}72.4 \% \\
(337) \\
\end{array}$ \\
\hline $\begin{array}{l}\text { Dad Completed } \\
\text { High School } \\
\& \text { Some College }\end{array}$ & $\begin{array}{l}53.6 \% \\
(69)\end{array}$ & $\begin{array}{l}77.8 \% \\
(243)\end{array}$ \\
\hline Dad Completed College & $\begin{array}{c}77.0 \% \\
(61) \\
\end{array}$ & $\begin{array}{l}87.0 \% \\
(300) \\
\end{array}$ \\
\hline \multicolumn{3}{|l|}{ By Ethnicity } \\
\hline Black & $\begin{array}{c}45.0 \% \\
(60) \\
\end{array}$ & $\begin{array}{l}61.0 \% \\
(392) \\
\end{array}$ \\
\hline Hispanic & $\begin{array}{c}48.6 \% \\
(72) \\
\end{array}$ & $\begin{array}{l}64.3 \% \\
(322) \\
\end{array}$ \\
\hline Other & $\begin{array}{l}62.0 \% \\
(276) \\
\end{array}$ & $\begin{array}{l}78.7 \% \\
(823) \\
\end{array}$ \\
\hline \multicolumn{3}{|c|}{ ***Excludes Missing Observations } \\
\hline \multicolumn{3}{|c|}{$\begin{array}{l}\text { Source: NLSY97; limited to those respondents who were juniors in high school in } 1997 \text {, } \\
\text { 1998, or } 1999 .\end{array}$} \\
\hline \multicolumn{3}{|c|}{$\begin{array}{l}\text { Smoker is defined to be those respondents who had at least one cigarette in the } 30 \text { days } \\
\text { preceding the respondent's interview. }\end{array}$} \\
\hline
\end{tabular}


B. Females

\begin{tabular}{|c|c|c|}
\hline \multicolumn{3}{|c|}{$\begin{array}{l}\text { Percentage of Female Youth who Graduated High School by Age } 19 \\
\text { (number in parentheses indicates total number of smokers or non-smokers) }\end{array}$} \\
\hline & $\begin{array}{c}\text { Smoker during Junior Year } \\
\text { of High School }\end{array}$ & $\begin{array}{c}\text { Non-Smoker during Junior } \\
\text { Year of High School }\end{array}$ \\
\hline \multicolumn{3}{|l|}{ By ASVAB Math } \\
\hline $\begin{array}{l}\text { Scored Below Median } \\
(1.03)\end{array}$ & $\begin{array}{l}65.1 \% \\
(209)\end{array}$ & $\begin{array}{l}72.3 \% \\
(600)\end{array}$ \\
\hline $\begin{array}{l}\text { Scored At or Above } \\
\text { Median (1.03) }\end{array}$ & $\begin{array}{l}84.7 \% \\
(163)\end{array}$ & $\begin{array}{l}89.5 \% \\
(647)\end{array}$ \\
\hline \multicolumn{3}{|l|}{ Mother's Education Level } \\
\hline $\begin{array}{l}\text { Mom Did Not } \\
\text { Complete High School }\end{array}$ & $\begin{array}{c}52.9 \% \\
(70)\end{array}$ & $\begin{array}{l}67.5 \% \\
(271)\end{array}$ \\
\hline $\begin{array}{l}\text { Mom Completed } \\
\text { High School }\end{array}$ & $\begin{array}{l}69.4 \% \\
(134)\end{array}$ & $\begin{array}{l}76.1 \% \\
(507)\end{array}$ \\
\hline $\begin{array}{l}\text { Mom Completed } \\
\text { High School } \\
\text { \& Some College }\end{array}$ & $\begin{array}{l}77.2 \% \\
(127)\end{array}$ & $\begin{array}{l}82.1 \% \\
(329)\end{array}$ \\
\hline $\begin{array}{l}\text { Mom Completed } \\
\text { College }\end{array}$ & $\begin{array}{c}84.5 \% \\
(58)\end{array}$ & $\begin{array}{l}90.4 \% \\
(291)\end{array}$ \\
\hline \multicolumn{3}{|l|}{$\begin{array}{l}\text { By Father's Education } \\
\text { Level }\end{array}$} \\
\hline $\begin{array}{l}\text { Dad Did Not } \\
\text { Complete High School }\end{array}$ & $\begin{array}{c}63.2 \% \\
(38)\end{array}$ & $\begin{array}{l}71.4 \% \\
(196)\end{array}$ \\
\hline $\begin{array}{l}\text { Dad Completed } \\
\text { High School }\end{array}$ & $\begin{array}{c}66.7 \% \\
(105)\end{array}$ & $\begin{array}{l}78.9 \% \\
(317)\end{array}$ \\
\hline $\begin{array}{l}\text { Dad Completed } \\
\text { High School } \\
\text { \& Some College }\end{array}$ & $\begin{array}{c}80.3 \% \\
(76)\end{array}$ & $\begin{array}{l}85.0 \% \\
(200)\end{array}$ \\
\hline Dad Completed College & $\begin{array}{c}87.5 \% \\
(64)\end{array}$ & $\begin{array}{l}87.7 \% \\
(285)\end{array}$ \\
\hline \multicolumn{3}{|l|}{ By Ethnicity } \\
\hline Black & $\begin{array}{c}80.0 \% \\
(55)\end{array}$ & $\begin{array}{l}73.9 \% \\
(440)\end{array}$ \\
\hline Hispanic & $\begin{array}{c}72.3 \% \\
(65)\end{array}$ & $\begin{array}{l}70.3 \% \\
(333)\end{array}$ \\
\hline Other & $\begin{array}{l}69.2 \% \\
(318)\end{array}$ & $\begin{array}{l}83.3 \% \\
(759)\end{array}$ \\
\hline \multicolumn{3}{|c|}{$* * *$ Excludes Missing Observations } \\
\hline \multicolumn{3}{|c|}{$\begin{array}{l}\text { Source: NLSY97; limited to those respondents who were juniors in high school in } 1997 \text {, } \\
1998 \text {, or } 1999 .\end{array}$} \\
\hline \multicolumn{3}{|c|}{$\begin{array}{l}\text { Smoker is defined to be those respondents who had at least one cigarette in the } 30 \text { days } \\
\text { preceding the respondent's interview. }\end{array}$} \\
\hline
\end{tabular}


Table 3

High School Graduation

Logit Regression results, coefficient estimates and z-statistic

All races

Selected explanatory variables

\begin{tabular}{|c|c|c|c|c|}
\hline & Smoker & Drinker & Frequent binger & ASVAB \\
\hline Males & & & & \\
$\mathrm{N}=1945$ & & & & .0570 \\
\hline Specification 1 & -.667 & & & {$[7.6]$} \\
\hline Specification 2 & {$[5.2]$} & & & .0564 \\
& {$[4.649$} & .081 & -.297 & {$[7.5]$} \\
\hline Females & & {$[.6]$} & {$[1.4]$} & \\
$\mathrm{N}=1970$ & -.322 & & & .0754 \\
\hline Specification 1 & {$[2.3]$} & & & {$[9.0]$} \\
\hline Specification 2 & -.256 & .025 & -.553 & .0754 \\
& {$[1.6]$} & {$[.2]$} & {$[2.0]$} & {$[9.0]$} \\
\hline
\end{tabular}

College Matriculation

Logit Regression results, coefficient estimates and z-statistic

All races

Selected explanatory variables

\begin{tabular}{|c|c|c|c|c|}
\hline & Smoker & Drinker & Frequent binger & ASVAB \\
\hline$\frac{\text { Males }}{N=1945}$ & & & & \\
\hline Specification 1 & $\begin{array}{c}-1.149 \\
{[5.9]}\end{array}$ & & & $\begin{array}{l}.1321 \\
{[12.2]}\end{array}$ \\
\hline Specification 2 & $\begin{array}{c}-1.168 \\
{[5.5]}\end{array}$ & $\begin{array}{l}.040 \\
{[.3]}\end{array}$ & $\begin{array}{c}.004 \\
{[0]}\end{array}$ & $\begin{array}{l}.1323 \\
{[12.1]}\end{array}$ \\
\hline$\frac{\text { Females }}{\mathrm{N}=1963}$ & & & & \\
\hline Specification 1 & $\begin{array}{l}-.670 \\
{[4.5]}\end{array}$ & & & $\begin{array}{l}.1144 \\
{[12.2]}\end{array}$ \\
\hline Specification 2 & $\begin{array}{l}-.563 \\
{[3.4]}\end{array}$ & $\begin{array}{c}-.033 \\
{[.2]}\end{array}$ & $\begin{array}{l}-.706 \\
{[2.0]}\end{array}$ & $\begin{array}{l}.1143 \\
{[12.1]}\end{array}$ \\
\hline
\end{tabular}

Note: All regressions include, in addition to the regressors shown, the following: indicators of respondent's race, mother's and father's education, household size, indicator of whether the family was intact, ln of household income, urban residence, regional indicators, cohort indicators, and indicators for month of interview 
Table 4

Smoking

Logit Regression results, coefficient estimates and z-statistic All Races

Selected explanatory variables

\begin{tabular}{|c|c|c|c|c|}
\hline & $\begin{array}{c}\text { High School } \\
\text { Graduate }\end{array}$ & $\begin{array}{c}\text { College } \\
\text { Matriculant }\end{array}$ & ASVAB & $\begin{array}{c}\text { \% of Peers who } \\
\text { smoke }\end{array}$ \\
\hline $\begin{array}{c}\text { Males } \\
\mathrm{N}=1894\end{array}$ & & & & \\
\hline Specification 1 & -.493 & -.985 & -.0216 & \\
\hline Specification 2 & {$[3.7]$} & {$[5.1]$} & {$[2.6]$} & \\
\hline$\underline{\text { Females }}$ & -.480 & -.953 & -.0175 & 1.196 \\
$\mathrm{~N}=1934$ & {$[3.6]$} & {$[4.9]$} & {$[2.1]$} & {$[4.7]$} \\
\hline Specification 1 & -.149 & -.693 & -.0237 & \\
& {$[1.0]$} & {$[4.5]$} & {$[2.9]$} & \\
\hline Specification 2 & -.114 & -.626 & -.0154 & 1.781 \\
& {$[.8]$} & {$[4.0]$} & {$[1.8]$} & {$[7.1]$} \\
\hline
\end{tabular}


Table 5

Drinking

Logit Regression results, coefficient estimates and z-statistic All Races

Selected explanatory variables

\begin{tabular}{|c|c|c|c|c|}
\hline & $\begin{array}{c}\text { High School } \\
\text { Graduate }\end{array}$ & $\begin{array}{c}\text { College } \\
\text { Matriculant }\end{array}$ & ASVAB & $\begin{array}{c}\% \text { of Peers who } \\
\text { smoke }\end{array}$ \\
\hline \multicolumn{5}{|l|}{$\underline{\mathrm{Males}}$} \\
\hline Specification 1 & $\begin{array}{c}-.086 \\
{[.7]} \\
\end{array}$ & $\begin{array}{l}-.345 \\
{[2.4]} \\
\end{array}$ & $\begin{array}{c}-.0098 \\
{[1.4]} \\
\end{array}$ & \\
\hline Specification 2 & $\begin{array}{c}-.078 \\
{[.7]} \\
\end{array}$ & $\begin{array}{l}-.327 \\
{[2.3]}\end{array}$ & $\begin{array}{c}-.0077 \\
{[1.1]} \\
\end{array}$ & $\begin{array}{l}.555 \\
{[2.5]}\end{array}$ \\
\hline \multicolumn{5}{|l|}{$\frac{\text { Females }}{\mathrm{N}=}$} \\
\hline Specification 1 & $\begin{array}{c}-.058 \\
{[.4]} \\
\end{array}$ & $\begin{array}{l}-.338 \\
{[2.6]}\end{array}$ & $\begin{array}{c}-.0069 \\
{[.9]}\end{array}$ & \\
\hline Specification 2 & $\begin{array}{c}-.036 \\
{[.3]}\end{array}$ & $\begin{array}{l}-.300 \\
{[2.3]}\end{array}$ & $\begin{array}{l}.0120 \\
{[1.6]} \\
\end{array}$ & $\begin{array}{l}.966 \\
{[4.4]}\end{array}$ \\
\hline
\end{tabular}

Note: All regressions include, in addition to the regressors shown, the following: state cigarette tax, race indicators, indicators of mother's and father's education, household size, indicator of whether the family was intact, ln of household income, urban residence, regional indicators, cohort indicators, and indicators for month of interview 


\begin{tabular}{|c|c|c|c|}
\hline \multicolumn{4}{|c|}{$\begin{array}{l}\text { Descriptive Statistics, Variable Definitions, and Sample Construction } \\
\text { All means \& standard deviations are weighted and exclude missing observations. }\end{array}$} \\
\hline \multirow[t]{2}{*}{ Variables } & \multicolumn{2}{|c|}{$\begin{array}{c}\text { Mean } \\
\text { (Standard Deviation) }\end{array}$} & \multirow[t]{2}{*}{ Definitions } \\
\hline & Males & Females & \\
\hline \multicolumn{4}{|l|}{$\frac{\text { Educational }}{\text { Attainment }}$} \\
\hline $\begin{array}{l}\text { High School } \\
\text { Graduate }\end{array}$ & $\begin{array}{l}0.7123 \\
(0.4512)\end{array}$ & $\begin{array}{l}0.7745 \\
(0.4194)\end{array}$ & $\begin{array}{l}\text { Education d.v.: } 1 \text { if youth } \\
\text { graduated high school by age } 19,0 \\
\text { otherwise. }\end{array}$ \\
\hline $\begin{array}{l}\text { Enrolled in } \\
\text { College }\end{array}$ & $\begin{array}{l}0.2579 \\
(0.4360)\end{array}$ & $\begin{array}{c}0.3301 \\
(0.4689)\end{array}$ & $\begin{array}{l}\text { Education d.v.: Enrolled in a } 4- \\
\text { year college in the year } \\
\text { immediately following high school } \\
\text { graduation }\end{array}$ \\
\hline \multicolumn{4}{|l|}{$\begin{array}{l}\text { Smoking/Drinking } \\
\text { Habits }\end{array}$} \\
\hline $\begin{array}{l}\text { Junior Year } \\
\text { Smoker }\end{array}$ & $\begin{array}{l}0.2243 \\
(0.4158)\end{array}$ & $\begin{array}{c}0.2586 \\
(0.4567)\end{array}$ & $\begin{array}{l}\text { Smoking d.v.: } 1 \text { if youth reported } \\
\text { smoking at least one or more } \\
\text { cigarettes per days in the past } 30 \\
\text { days during junior of high school }\end{array}$ \\
\hline $\begin{array}{l}\text { Junior Year } \\
\text { Drinker }\end{array}$ & $\begin{array}{l}0.3702 \\
(0.4812)\end{array}$ & $\begin{array}{l}0.3559 \\
(0.4805)\end{array}$ & $\begin{array}{l}\text { Drinking d.v.: } 1 \text { if youth reports } \\
\text { any drinking in the past } 30 \text { days } \\
\text { during junior year of high school }\end{array}$ \\
\hline $\begin{array}{l}\text { Missing Junior } \\
\text { Year Drinker }\end{array}$ & $\begin{array}{c}0.0254 \\
(0.1567)\end{array}$ & $\begin{array}{c}0.0182 \\
(0.1341)\end{array}$ & $\begin{array}{l}\text { Missing Data d.v.: } 1 \text { if drinking } \\
\text { habits were not reported } \\
\text { Drinking d.v.: } 1 \text { if youth reports }\end{array}$ \\
\hline $\begin{array}{l}\text { Junior Year } \\
\text { Frequent Binge } \\
\text { Drinker }\end{array}$ & $\begin{array}{l}0.1107 \\
(0.3122)\end{array}$ & $\begin{array}{c}0.0662 \\
(0.2500)\end{array}$ & $\begin{array}{l}\text { drinking on } 5 \text { or more drinks on } 4 \\
\text { or more occasions during the past } \\
30 \text { days during junior year of high } \\
\text { school }\end{array}$ \\
\hline $\begin{array}{l}\text { Missing Junior } \\
\text { Year Frequent } \\
\text { Binge Drinker }\end{array}$ & $\begin{array}{l}0.2098 \\
(0.4059)\end{array}$ & $\begin{array}{c}0.2528 \\
(0.4361)\end{array}$ & $\begin{array}{l}\text { Missing Data d.v.: } 1 \text { if drinking } \\
\text { habits were not reported, } 0 \\
\text { otherwise. }\end{array}$ \\
\hline \multicolumn{4}{|l|}{ State Level Indicators } \\
\hline $\begin{array}{l}\text { State Cigarette Tax } \\
\text { Index }\end{array}$ & $\begin{array}{c}40.90 \\
(23.77)\end{array}$ & $\begin{array}{l}38.40 \\
(24.34)\end{array}$ & \\
\hline $\begin{array}{l}\text { Missing State } \\
\text { Cigarette Tax } \\
\text { Index }\end{array}$ & $\begin{array}{c}0.0337 \\
(0.1798)\end{array}$ & $\begin{array}{c}0.0185 \\
(0.1549)\end{array}$ & $\begin{array}{l}\text { Missing Data d.v.: } 1 \text { if tax index } \\
\text { was not reported }\end{array}$ \\
\hline $\begin{array}{l}\text { State Beer Tax } \\
\text { Index }\end{array}$ & $\begin{array}{c}0.4834 \\
(0.0852)\end{array}$ & $\begin{array}{c}0.4883 \\
(0.0902)\end{array}$ & \\
\hline $\begin{array}{l}\text { Missing State Beer } \\
\text { Tax Index }\end{array}$ & $\begin{array}{c}0.0263 \\
(0.1594)\end{array}$ & $\begin{array}{c}0.0185 \\
(0.1353)\end{array}$ & $\begin{array}{l}\text { Missing Data d.v.: } 1 \text { if tax index } \\
\text { was not reported }\end{array}$ \\
\hline
\end{tabular}




\begin{tabular}{|c|c|c|c|}
\hline$\frac{\text { Race \& Ethnicity }}{\text { Black }}$ & $\begin{array}{c}0.1339 \\
(0.3394) \\
0.1311 \\
(0.3364)\end{array}$ & $\begin{array}{c}0.1529 \\
(0.3612) \\
0.1157 \\
(0.3210)\end{array}$ & $\begin{array}{l}\text { Race d.v.: } 1 \text { if black } \\
\text { Race d.v.: } 1 \text { if Hispanic }\end{array}$ \\
\hline \multicolumn{4}{|l|}{ Parent's Education } \\
\hline $\begin{array}{l}\text { Mother Did Not } \\
\text { Finish High } \\
\text { School }\end{array}$ & $\begin{array}{c}0.1380 \\
(0.3441)\end{array}$ & $\begin{array}{c}0.1392 \\
(0.3470)\end{array}$ & $\begin{array}{l}\text { Parent's Education d.v.: } 1 \text { if } \\
\text { Mother did not complete high } \\
\text { school }\end{array}$ \\
\hline $\begin{array}{l}\text { Mother Finished } \\
\text { High School }\end{array}$ & $\begin{array}{c}0.3770 \\
(0.4835)\end{array}$ & $\begin{array}{c}0.3564 \\
(0.4802)\end{array}$ & $\begin{array}{l}\text { Parent's Education d.v.: } 1 \text { if } \\
\text { Mother completed high school but } \\
\text { did not attend any college }\end{array}$ \\
\hline $\begin{array}{l}\text { Mother Completed } \\
\text { Some College }\end{array}$ & $\begin{array}{c}0.2638 \\
(0.4397)\end{array}$ & $\begin{array}{c}0.2754 \\
(0.4464)\end{array}$ & $\begin{array}{l}\text { Parent's Education d.v.: } 1 \text { if } \\
\text { Mother completed some college }\end{array}$ \\
\hline Mother Finished & 0.2212 & 0.2290 & Parent's Education d.v.: 1 if \\
\hline College & $(0.4141)$ & $(0.4213)$ & Mother completed college \\
\hline Missing Mother's & 0.0883 & 0.0840 & Missing Data d.v.: 1 if Mother's \\
\hline Father Did Not & $(0.2828)$ & $(0.2 / 84)$ & education level was not reported \\
\hline $\begin{array}{l}\text { Finish High } \\
\text { School }\end{array}$ & $\begin{array}{c}0.1416 \\
(0.3490)\end{array}$ & $\begin{array}{c}0.1411 \\
(0.3479)\end{array}$ & $\begin{array}{l}\text { Parent's Education d.v.: } 1 \text { if Father } \\
\text { did not complete high school }\end{array}$ \\
\hline $\begin{array}{l}\text { Father Finished } \\
\text { High School }\end{array}$ & $\begin{array}{c}0.3200 \\
(0.4669)\end{array}$ & $\begin{array}{c}0.3318 \\
(0.4706)\end{array}$ & $\begin{array}{l}\text { Parent's Education d.v.: } 1 \text { if Father } \\
\text { completed high school but did not } \\
\text { attend any college }\end{array}$ \\
\hline $\begin{array}{l}\text { Father Completed } \\
\text { Some College }\end{array}$ & $\begin{array}{c}0.2379 \\
(0.4262)\end{array}$ & $\begin{array}{c}0.2184 \\
(0.4129)\end{array}$ & $\begin{array}{l}\text { Parent's Education d.v.: } 1 \text { if Father } \\
\text { completed some college }\end{array}$ \\
\hline Father Finished & 0.3004 & 0.3088 & Parent's Education d.v.: 1 if Father \\
\hline College & $(0.4589)$ & $(0.4617)$ & completed college \\
\hline $\begin{array}{l}\text { Missing Father's } \\
\text { Education Level }\end{array}$ & $\begin{array}{c}0.2598 \\
(0.4371)\end{array}$ & $\begin{array}{r}0.2918 \\
(0.4562)\end{array}$ & Missing Data d.v.: 1 if Father \\
\hline \multicolumn{4}{|l|}{ Family \& Household } \\
\hline Household Size & $\begin{array}{c}4.3217 \\
(1.3660)\end{array}$ & $\begin{array}{c}4.2944 \\
(1.4820)\end{array}$ & $\begin{array}{l}\text { Number of persons living in } \\
\text { Household with youth. }\end{array}$ \\
\hline $\begin{array}{l}\text { Missing } \\
\text { Household Size }\end{array}$ & $\begin{array}{c}0.0246 \\
(0.1543)\end{array}$ & $\begin{array}{c}0.0165 \\
(0.1278)\end{array}$ & $\begin{array}{l}\text { Missing data d.v.: } 1 \text { if household } \\
\text { size was not reported }\end{array}$ \\
\hline $\begin{array}{l}\text { Family Intact in } \\
1997\end{array}$ & $\begin{array}{c}0.7695 \\
(0.4197)\end{array}$ & $\begin{array}{c}0.7278 \\
(0.4467)\end{array}$ & $\begin{array}{l}\text { Family d.v. } 1 \text { if youth lived with } \\
\text { both biological, step, or adopted } \\
\text { parents in } 1997\end{array}$ \\
\hline $\begin{array}{l}\text { Missing Family } \\
\text { Intact in } 1997\end{array}$ & & $\begin{array}{c}0.0018 \\
(0.0424)\end{array}$ & $\begin{array}{l}\text { Missing data d.v.: } 1 \text { if family } \\
\text { intact data was not reported }\end{array}$ \\
\hline $\begin{array}{l}\text { Household Income } \\
\text { (Ln) }\end{array}$ & $\begin{array}{l}10.6728 \\
(0.9102)\end{array}$ & $\begin{array}{l}10.6222 \\
(1.0256)\end{array}$ & $\begin{array}{l}\text { Log of household income reported } \\
\text { by youth. }\end{array}$ \\
\hline Income Missing & $\begin{array}{l}0.7475 \\
(0.4330)\end{array}$ & $\begin{array}{c}0.7014 \\
(0.4592)\end{array}$ & $\begin{array}{l}\text { Missing data d.v.: } 1 \text { if income data } \\
\text { was not reported }\end{array}$ \\
\hline
\end{tabular}




\begin{tabular}{|c|c|c|c|}
\hline \multicolumn{3}{|l|}{$\underline{\text { Aptitude }}$} & \multirow{3}{*}{$\begin{array}{l}\text { ASVAB Math Aptitude Score, } \\
\text { divided by } 100 . \text { Scores were } \\
\text { scaled such the median was " } 0 " \\
\text { Missing Data d.v.: } 1 \text { if Math } \\
\text { ASVAB score was not reported }\end{array}$} \\
\hline $\begin{array}{l}\text { Math ASVAB } \\
\text { Score }\end{array}$ & $\begin{array}{c}1.9771 \\
(9.2245)\end{array}$ & $\begin{array}{c}3.2417 \\
(8.9102)\end{array}$ & \\
\hline $\begin{array}{l}\text { Missing Math } \\
\text { ASVAB }\end{array}$ & $\begin{array}{c}0.1730 \\
(0.3770)\end{array}$ & $\begin{array}{c}0.1635 \\
(0.3711)\end{array}$ & \\
\hline \multicolumn{4}{|l|}{ Peers } \\
\hline $\begin{array}{l}\text { Percentages of } \\
\text { respondent's peer } \\
\text { who smoke }\end{array}$ & $\begin{array}{c}0.3364 \\
(0.2367)\end{array}$ & $\begin{array}{c}0.4038 \\
(0.2534)\end{array}$ & $\begin{array}{l}\text { Self-reported fraction of peers that } \\
\text { respondents report as smokers. }\end{array}$ \\
\hline \multicolumn{4}{|l|}{ Demographics } \\
\hline Urbanity & $\begin{array}{c}0.7192 \\
(0.4484)\end{array}$ & $\begin{array}{c}0.7072 \\
(0.4562)\end{array}$ & $\begin{array}{l}\text { Demographic d.v.: } 1 \text { if youth } \\
\text { reports living in an urban region }\end{array}$ \\
\hline Missing Urban & $\begin{array}{c}0.0566 \\
(0.2302)\end{array}$ & $\begin{array}{c}0.0474 \\
(0.2131)\end{array}$ & $\begin{array}{l}\text { Missing Data d.v.: } 1 \text { if no } \\
\text { urban/rural information is reported }\end{array}$ \\
\hline Body Weight & $\begin{array}{l}162.4 \\
(34.0)\end{array}$ & $\begin{array}{l}133.2 \\
(27.5)\end{array}$ & Youth's body weight in pounds. \\
\hline Missing Weight & $\begin{array}{c}0.0298 \\
(0.1696)\end{array}$ & $\begin{array}{c}0.0401 \\
(0.1970)\end{array}$ & $\begin{array}{l}\text { Missing Data d.v.: } 1 \text { if no weight } \\
\text { was reported }\end{array}$ \\
\hline South & $\begin{array}{c}0.2996 \\
(0.4567)\end{array}$ & $\begin{array}{c}0.3394 \\
(0.4750)\end{array}$ & $\begin{array}{l}\text { Demographic d.v.: } 1 \text { if youth lives } \\
\text { in South Census Region }\end{array}$ \\
\hline West & $\begin{array}{c}0.2258 \\
(0.4169)\end{array}$ & $\begin{array}{c}0.2126 \\
(0.4104)\end{array}$ & \\
\hline Northeast & $\begin{array}{c}0.1911 \\
(0.3920)\end{array}$ & $\begin{array}{c}0.1795 \\
(0.3850)\end{array}$ & \\
\hline North Central & $\begin{array}{c}0.2817 \\
(0.4485)\end{array}$ & $\begin{array}{c}0.2671 \\
(0.4439)\end{array}$ & \\
\hline $\begin{array}{l}\text { Missing Census } \\
\text { Reoion }\end{array}$ & $\begin{array}{l}0.0246 \\
(0.1543)\end{array}$ & 0.0164 & \\
\hline Cohort 1 & $\begin{array}{c}0.3196 \\
(0.0727)\end{array}$ & $\begin{array}{c}0.3535 \\
(0.4797)\end{array}$ & $\begin{array}{l}\text { Sample d.v.: } 1 \text { if youth was a } \\
\text { junior in high school in } 1997\end{array}$ \\
\hline Cohort 2 & $\begin{array}{c}0.3621 \\
(0.4790)\end{array}$ & $\begin{array}{c}0.3324 \\
(0.4727)\end{array}$ & $\begin{array}{l}\text { Sample d.v.: } 1 \text { if youth was a } \\
\text { junior in high school in } 1998\end{array}$ \\
\hline Cohort 3 & $\begin{array}{l}0.3183 \\
(0.4643)\end{array}$ & $\begin{array}{c}0.3141 \\
(0.4658)\end{array}$ & $\begin{array}{l}\text { Sample d.v.: } 1 \text { if youth was a } \\
\text { junior in high school in } 1999\end{array}$ \\
\hline \multicolumn{4}{|l|}{ Interaction Terms } \\
\hline \multicolumn{4}{|l|}{ Month of Interview } \\
\hline January & $\begin{array}{c}0.1158 \\
(0.3190)\end{array}$ & $\begin{array}{c}0.1188 \\
(0.3247)\end{array}$ & $\begin{array}{l}\text { Month of interview d.v.: } 1 \text { if youth } \\
\text { was interview of during January of } \\
\text { junior year }\end{array}$ \\
\hline February & 0.1039 & 0.1077 & \\
\hline March & 0.0997 & 0.0953 & \\
\hline April & 0.1051 & 0.1118 & \\
\hline May & 0.0640 & 0.0749 & \\
\hline June & 0.0391 & 0.0406 & \\
\hline
\end{tabular}




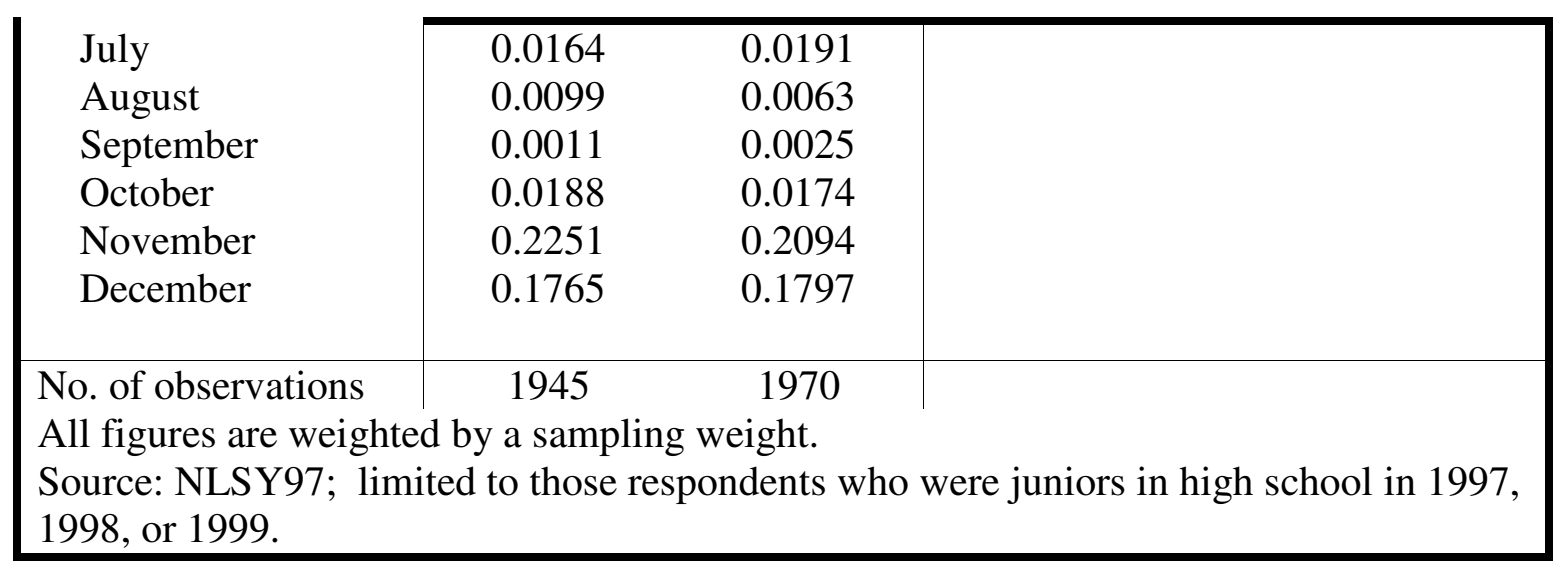


Table A2

\begin{tabular}{|c|c|c|c|c|}
\hline \multicolumn{5}{|c|}{ Educational Attainment: Association with Smoking in $11^{\text {th }}$ Grade } \\
\hline \multicolumn{5}{|c|}{ Logit Estimates, Coefficients, and Standard Errors } \\
\hline & \multicolumn{2}{|c|}{ Graduated High School by Age 19} & \multicolumn{2}{|c|}{$\begin{array}{c}\text { Enrolled in a 4-year college the } \\
\text { year following high school } \\
\text { graduation }\end{array}$} \\
\hline $\begin{array}{l}\text { Smoker during the } 11^{\text {th }} \text { grade } \\
\text { Race \& Ethnicity }\end{array}$ & $\begin{array}{l}\frac{\text { Males }}{-0.6822^{a}} \\
(0.1436)\end{array}$ & $\begin{array}{l}\text { Females } \\
-0.3070^{c} \\
(0.1593)\end{array}$ & $\begin{array}{l}\frac{\text { Males }}{-0.9751^{a}} \\
(0.2077)\end{array}$ & $\begin{array}{l}\frac{\text { Females }}{-0.6404^{\mathrm{a}}} \\
(0.1623)\end{array}$ \\
\hline Black & $\begin{array}{l}-0.1482 \\
(0.1745)\end{array}$ & $\begin{array}{r}0.5525^{\mathrm{a}} \\
(0.1984)\end{array}$ & $\begin{array}{c}0.2444 \\
(0.2120)\end{array}$ & $\begin{array}{r}0.7390^{\mathrm{a}} \\
(0.1819)\end{array}$ \\
\hline Hispanic & $\begin{array}{l}-0.2620 \\
(0.1784)\end{array}$ & $\begin{array}{r}0.3942^{c} \\
(0.2110)\end{array}$ & $\begin{array}{l}-0.2264 \\
(0.2413)\end{array}$ & $\begin{array}{c}0.0328 \\
(0.2041)\end{array}$ \\
\hline \multicolumn{5}{|l|}{$\begin{array}{l}\text { Parent's Education Levels } \\
\text { (Defaults: } \\
\text { Mom is school dropout } \\
\text { Dad is school dropout) }\end{array}$} \\
\hline $\begin{array}{l}\text { Mom Finished High } \\
\text { School }\end{array}$ & $\begin{array}{c}0.2570 \\
(0.1936)\end{array}$ & $\begin{array}{c}0.2007 \\
(0.2079)\end{array}$ & $\begin{array}{c}0.7271^{\mathrm{b}} \\
(0.3174)\end{array}$ & $\begin{array}{c}0.1078 \\
(0.2369)\end{array}$ \\
\hline $\begin{array}{l}\text { Mom Finished Some } \\
\text { College }\end{array}$ & $\begin{array}{c}0.2742 \\
(0.2133)\end{array}$ & $\begin{array}{r}0.4251^{\mathrm{c}} \\
(0.2339)\end{array}$ & $\begin{array}{r}0.9196^{\mathrm{a}} \\
(0.3246)\end{array}$ & $\begin{array}{c}0.3825 \\
(0.2482)\end{array}$ \\
\hline Mom Finished College & $\begin{array}{r}0.5846^{\mathrm{b}} \\
(0.2687)\end{array}$ & $\begin{array}{r}0.8105^{\mathrm{a}} \\
(0.3028)\end{array}$ & $\begin{array}{r}1.2133^{\mathrm{a}} \\
(0.3410)\end{array}$ & $\begin{array}{r}1.1179^{\mathrm{a}} \\
(0.2666)\end{array}$ \\
\hline $\begin{array}{l}\text { Dad Finished High } \\
\text { School }\end{array}$ & $\begin{array}{c}0.1799 \\
(0.2239)\end{array}$ & $\begin{array}{l}-0.0639 \\
(0.2486)\end{array}$ & $\begin{array}{l}-0.6311^{\mathrm{c}} \\
(0.3238)\end{array}$ & $\begin{array}{c}0.3649 \\
(0.2623)\end{array}$ \\
\hline $\begin{array}{l}\text { Dad Finished Some } \\
\text { College } \\
\text { Dad Finished College }\end{array}$ & $\begin{array}{c}0.1328 \\
(0.2481) \\
0.7008^{\mathrm{b}} \\
(0.2863)\end{array}$ & $\begin{array}{c}0.6629^{\mathrm{b}} \\
(0.2988) \\
0.4091 \\
(0.3085)\end{array}$ & $\begin{array}{l}-0.1068 \\
(0.3223) \\
0.6354^{\mathrm{c}} \\
(0.3274)\end{array}$ & $\begin{array}{r}0.6282^{b} \\
(0.2785) \\
0.5923^{b} \\
(0.2821)\end{array}$ \\
\hline$\frac{\text { Family \& Household }}{\text { Household Size }}$ & $\begin{array}{l}-0.0476 \\
(0.0449)\end{array}$ & $\begin{array}{l}-0.0350 \\
(0.0465)\end{array}$ & $\begin{array}{c}0.0185 \\
(0.0581)\end{array}$ & $\begin{array}{l}-0.0905^{\mathrm{c}} \\
(0.0487)\end{array}$ \\
\hline Family Intact in 1997 & $\begin{array}{r}0.3306^{\mathrm{c}} \\
(0.1828)\end{array}$ & $\begin{array}{c}0.2484 \\
(0.2114)\end{array}$ & $\begin{array}{c}0.0182 \\
(0.2464)\end{array}$ & $\begin{array}{c}0.3030 \\
(0.2216)\end{array}$ \\
\hline Household Income (Ln) & $\begin{array}{l}-0.0045 \\
(0.1408)\end{array}$ & $\begin{array}{c}0.0803 \\
(0.1111)\end{array}$ & $\begin{array}{c}0.1608 \\
(0.2078)\end{array}$ & $\begin{array}{c}0.1751 \\
(0.1277)\end{array}$ \\
\hline \multicolumn{5}{|l|}{$\underline{\text { Other }}$} \\
\hline Math ASVAB Score & $\begin{array}{r}0.0575^{\mathrm{a}} \\
(0.0078) \\
\end{array}$ & $\begin{array}{r}0.0785^{\mathrm{a}} \\
(0.0088)\end{array}$ & $\begin{array}{r}0.1370^{\mathrm{a}} \\
(0.0113)\end{array}$ & $\begin{array}{r}0.1177^{\mathrm{a}} \\
(0.0097) \\
\end{array}$ \\
\hline $\begin{array}{l}\text { R-squared } \\
\text { No. of observations }\end{array}$ & $\begin{array}{l}0.1354 \\
1580\end{array}$ & $\begin{array}{l}0.1537 \\
1616\end{array}$ & $\begin{array}{l}0.2919 \\
1578\end{array}$ & $\begin{array}{l}0.2279 \\
1613\end{array}$ \\
\hline \multicolumn{5}{|c|}{ a,b,c Significantly different than zero at the $1 \%, 5 \%$, or $10 \%$ level respectively } \\
\hline \multicolumn{5}{|c|}{ Source: NLSY97; limited to those respondents who were juniors in high school in 1997, 1998, or 1999.} \\
\hline \multicolumn{5}{|c|}{$\begin{array}{l}\text { Smoker is defined to be those respondents who had at least one cigarette in the } 30 \text { days preceding the respondent's interview. } \\
\text { Other variables included are indicators for urban residence, census region, body weight, cohorts (which year the respondent was a junior: 1997, 1998, } \\
\text { and 1999), month of interview indicators as well as missing variable indicators for state level indicators, parent's education levels, household income, } \\
\text { ASVAB scores, urban residence, body weight, and census region. }\end{array}$} \\
\hline
\end{tabular}


Table A3

High School Graduation

Logit Regression results, coefficient estimates and z-statistic

White, Asian and other

\begin{tabular}{|l|l|l|l|l|}
\hline \multicolumn{5}{|c|}{ Selected covariates } \\
\hline Males & Smoker & Drinker & Frequent binger & ASVAB \\
\hline $\mathrm{N}=1099$ & & & & \\
\hline Smoking only & -.705 & & & \\
& {$[4.2]$} & & & .0609 \\
& -.607 & .117 & -.741 & {$[5.7]$} \\
\hline Smoking \& & {$[3.3]$} & {$[.6]$} & {$[2.9]$} & .0593 \\
Drinking & & & & {$[5.5]$} \\
\hline Females & & & & \\
\hline $\mathrm{N}=1074$ & -.638 & & & .0845 \\
\hline Smoking & {$[3.6]$} & & {$[6.7]$} \\
& -.593 & .138 & -.636 & .0845 \\
\hline Smoking \& & {$[3.0]$} & {$[.7]$} & {$[1.9]$} & {$[6.7]$} \\
Drinking & & & & \\
\hline
\end{tabular}

College Matriculation

Logit Regression results, coefficient estimates and z-statistic

White, Asian and other

\begin{tabular}{|c|c|c|c|c|}
\hline \multicolumn{5}{|c|}{ ed covariates } \\
\hline \multirow{2}{*}{$\frac{\text { Males }}{\mathrm{N}=1099}$} & Smoker & Drinker & Frequent binger & ASVAB \\
\hline & & & & \\
\hline Smoking only & $\begin{array}{c}-1.162 \\
{[5.2]}\end{array}$ & & & $\begin{array}{l}.1505 \\
{[10.4]}\end{array}$ \\
\hline $\begin{array}{l}\text { Smoking \& } \\
\text { Drinking }\end{array}$ & $\begin{array}{c}-1.205 \\
{[4.9]}\end{array}$ & $\begin{array}{l}.004 \\
{[0]}\end{array}$ & $\begin{array}{l}.184 \\
{[.6]}\end{array}$ & $\begin{array}{l}.1516 \\
{[10.3]}\end{array}$ \\
\hline$\frac{\text { Females }}{\mathrm{N}=1072}$ & & & & \\
\hline Smoking & $\begin{array}{l}-.712 \\
{[4.0]}\end{array}$ & & & $\begin{array}{l}.1294 \\
{[9.7]}\end{array}$ \\
\hline $\begin{array}{l}\text { Smoking \& } \\
\text { Drinking }\end{array}$ & $\begin{array}{l}-.722 \\
{[3.6]}\end{array}$ & $\begin{array}{l}.209 \\
{[1.2]}\end{array}$ & $\begin{array}{l}-.578 \\
{[1.5]}\end{array}$ & $\begin{array}{l}.1283 \\
{[9.6]}\end{array}$ \\
\hline
\end{tabular}

Note: All regressions include, in addition to the regressors shown, the following: indicators of mother's and father's education, household size, indicator of whether the family was intact, ln of household income, urban residence, regional indicators, cohort indicators, and indicators for month of interview 
Table A4

\begin{tabular}{|c|c|c|c|c|}
\hline \multicolumn{5}{|c|}{ Smoking in $11^{\text {th }}$ Grade: Association with Subsequent Schooling } \\
\hline \multicolumn{5}{|c|}{ Logit Estimates, Coefficients, and Standard Errors } \\
\hline Educational Attainment & $\underline{\text { Males }}$ & $\underline{\text { Females }}$ & $\underline{\text { Males }}$ & $\underline{\text { Females }}$ \\
\hline High School Graduate & $\begin{array}{l}-0.6792^{\mathrm{a}} \\
(0.1446)\end{array}$ & $\begin{array}{l}-0.2815^{\mathrm{c}} \\
(0.1590)\end{array}$ & - & - \\
\hline Enrolled in College & - & - & $\begin{array}{r}0.9674^{\mathrm{a}} \\
(0.2006)\end{array}$ & $\begin{array}{l}-0.6836^{\mathrm{a}} \\
(0.1618)\end{array}$ \\
\hline$\frac{\text { State Level Indicators }}{\text { State Cigarette Tax Index }}$ & $\begin{array}{l}-0.0061^{\mathrm{c}} \\
(0.0035)\end{array}$ & $\begin{array}{l}-0.0074^{\mathrm{b}} \\
(0.0033)\end{array}$ & $\begin{array}{l}-0.0055 \\
(0.0035)\end{array}$ & $\begin{array}{l}-0.0078^{\mathrm{b}} \\
(0.0033)\end{array}$ \\
\hline$\underline{\text { Race \& Ethnicity }}$ & & & & \\
\hline Black & $\begin{array}{l}-1.3769^{\mathrm{a}} \\
(0.2096)\end{array}$ & $\begin{array}{l}-1.5261^{\mathrm{a}} \\
(0.2052)\end{array}$ & $\begin{array}{l}-1.1333^{\mathrm{a}} \\
(0.2081)\end{array}$ & $\begin{array}{l}-1.4933^{\mathrm{a}} \\
(0.2056)\end{array}$ \\
\hline Hispanic & $\begin{array}{l}-0.4664^{\mathrm{b}} \\
(0.1974)\end{array}$ & $\begin{array}{l}-0.7785^{\mathrm{a}} \\
(0.2009)\end{array}$ & $\begin{array}{l}-0.4572^{\mathrm{b}} \\
(0.1959)\end{array}$ & $\begin{array}{l}-0.7881^{\mathrm{a}} \\
(0.2007)\end{array}$ \\
\hline$\underline{\text { Parent's Education Levels }}$ & & & & \\
\hline $\begin{array}{l}\text { (Defaults: } \\
\text { Mom is school dropout } \\
\text { Dad is school dropout) }\end{array}$ & & & & \\
\hline $\begin{array}{l}\text { Mom Finished High } \\
\text { School }\end{array}$ & $\begin{array}{l}-0.0 .257 \\
(0.2181)\end{array}$ & $\begin{array}{l}-0.1511 \\
(0.2166)\end{array}$ & $\begin{array}{l}-0.0390 \\
(0.2148)\end{array}$ & $\begin{array}{l}-0.1783 \\
(0.2172)\end{array}$ \\
\hline $\begin{array}{l}\text { Mom Finished Some } \\
\text { College }\end{array}$ & $\begin{array}{c}0.2200 \\
(0.2347)\end{array}$ & $\begin{array}{c}0.1165 \\
(0.2280)\end{array}$ & $\begin{array}{c}0.2231 \\
(0.2319)\end{array}$ & $\begin{array}{c}0.1188 \\
(0.2286)\end{array}$ \\
\hline Mom Finished College & $\begin{array}{c}0.2121 \\
(0.2752)\end{array}$ & $\begin{array}{l}-0.4866^{\mathrm{c}} \\
(0.2704)\end{array}$ & $\begin{array}{c}0.2673 \\
(0.2739)\end{array}$ & $\begin{array}{l}-0.3922 \\
(0.2727)\end{array}$ \\
\hline $\begin{array}{l}\text { Dad Finished High } \\
\text { School }\end{array}$ & $\begin{array}{l}-0.2221 \\
(0.2457)\end{array}$ & $\begin{array}{r}0.4971^{c} \\
(0.2615)\end{array}$ & $\begin{array}{l}-0.3001 \\
(0.2433)\end{array}$ & $\begin{array}{r}0.5172^{\mathrm{b}} \\
(0.2619)\end{array}$ \\
\hline $\begin{array}{l}\text { Dad Finished Some } \\
\text { College }\end{array}$ & $\begin{array}{l}-0.1038 \\
(0.2669)\end{array}$ & $\begin{array}{r}0.6030^{\mathrm{b}} \\
(0.2802)\end{array}$ & $\begin{array}{l}-0.1101 \\
(0.2645)\end{array}$ & $\begin{array}{r}0.6419^{\mathrm{b}} \\
(0.2808)\end{array}$ \\
\hline Dad Finished College & $\begin{array}{l}-0.4960^{c} \\
(0.2892)\end{array}$ & $\begin{array}{c}0.2153 \\
(0.2927)\end{array}$ & $\begin{array}{l}-0.4219 \\
(0.2896)\end{array}$ & $\begin{array}{c}0.2604 \\
(0.2936)\end{array}$ \\
\hline$\underline{\text { Family \& Household }}$ & & & & \\
\hline Household Size & $\begin{array}{l}-0.0338 \\
(0.0496)\end{array}$ & $\begin{array}{l}-0.1118^{\mathrm{b}} \\
(0.0483)\end{array}$ & $\begin{array}{l}-0.0221 \\
(0.0496)\end{array}$ & $\begin{array}{l}-0.1137^{\mathrm{b}} \\
(0.0480)\end{array}$ \\
\hline Family Intact in 1997 & $\begin{array}{l}-0.2680 \\
(0.2083)\end{array}$ & $\begin{array}{r}0.6056^{\mathrm{a}} \\
(0.2088)\end{array}$ & $\begin{array}{l}-0.3226 \\
(0.2075)\end{array}$ & $\begin{array}{r}0.6251^{\mathrm{a}} \\
(0.2084)\end{array}$ \\
\hline Household Income (Ln) & $\begin{array}{c}0.0589 \\
(0.1497)\end{array}$ & $\begin{array}{c}0.0162 \\
(0.1108)\end{array}$ & $\begin{array}{c}0.0700 \\
(0.1516)\end{array}$ & $\begin{array}{c}0.0172 \\
(0.1114)\end{array}$ \\
\hline Other & & & & \\
\hline Math ASVAB Score & $\begin{array}{l}-0.0363^{\mathrm{a}} \\
(0.0083)\end{array}$ & $\begin{array}{l}-0.0335^{\mathrm{a}} \\
(0.0083)\end{array}$ & $\begin{array}{l}-0.0301^{\mathrm{a}} \\
(0.0085)\end{array}$ & $\begin{array}{l}-0.0257^{\mathrm{a}} \\
(0.0085)\end{array}$ \\
\hline R-squared & 0.0710 & 0.0883 & 0.0734 & 0.0972 \\
\hline No. of observations & 1551 & 1605 & 1151 & 1605 \\
\hline
\end{tabular}


Figure 1: Probability of High School Graduation for different groups of $11^{\text {th }}$ graders

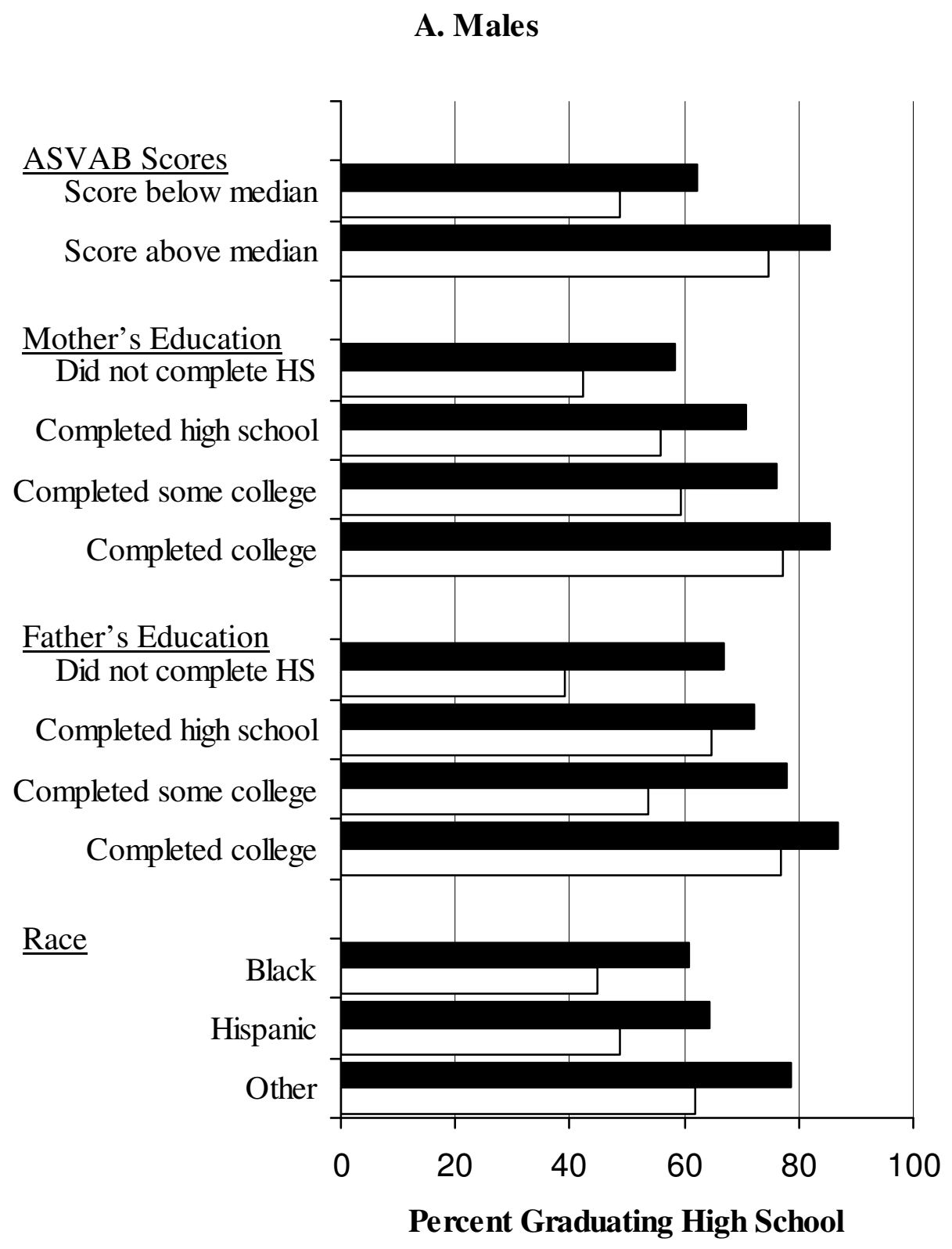

$\square$ Male Smoker $\square$ Male Nonsmoker 


\section{B. Females}

ASVAB Scores Score below median

Score above median

Mother's Education

Did not complete HS

Completed high school

Completed some college

Completed college

Father's Education

Did not complete HS

Completed high school

Completed some college

Completed college

$\underline{\text { Race }}$
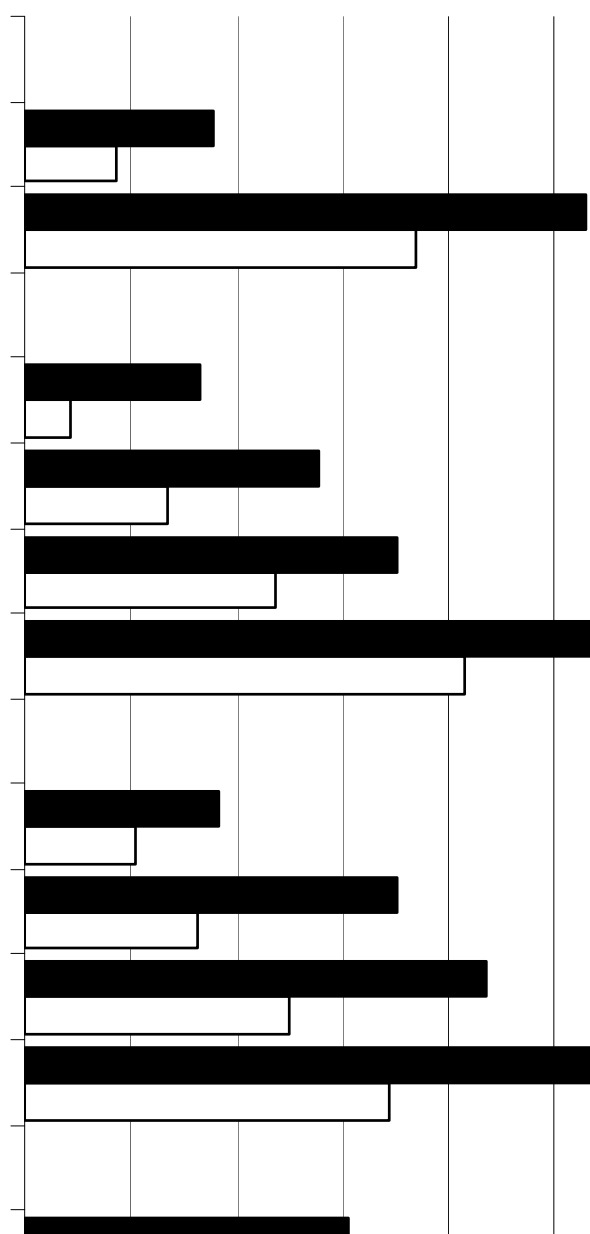

Black

Hispanic

Other
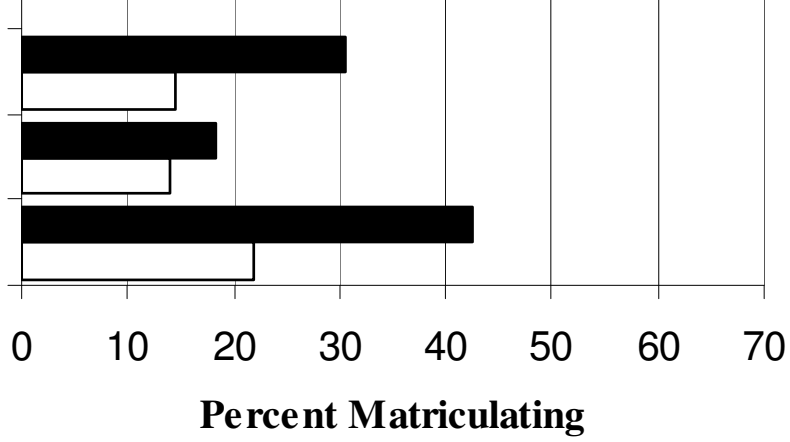

\section{Female Smoker Female Nonsmoker}


Figure 2: Probability of College Matriculation for different groups of $11^{\text {th }}$ Graders

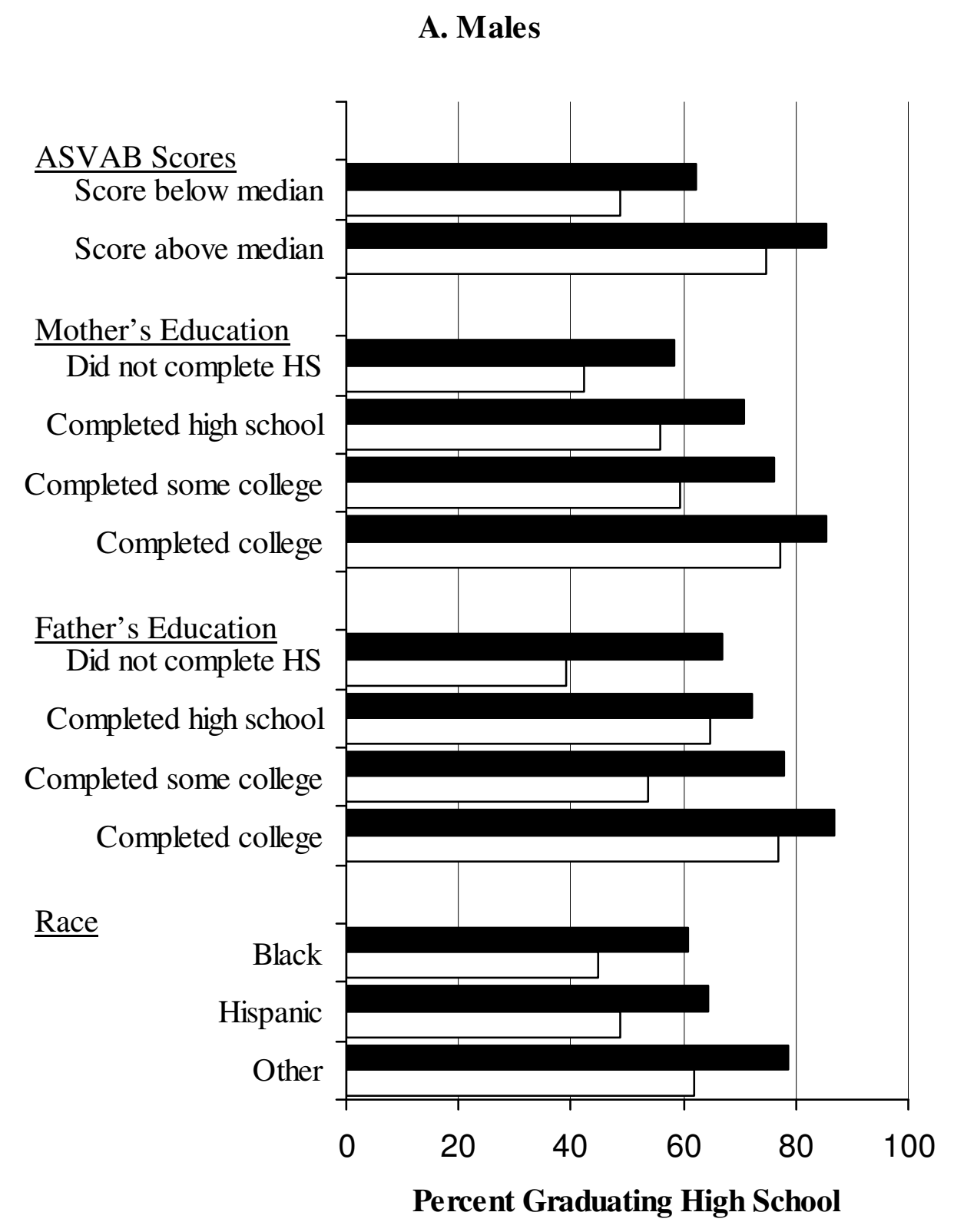

$\square$ Male Smoker $\square$ Male Nonsmoker 


\section{B. Females}

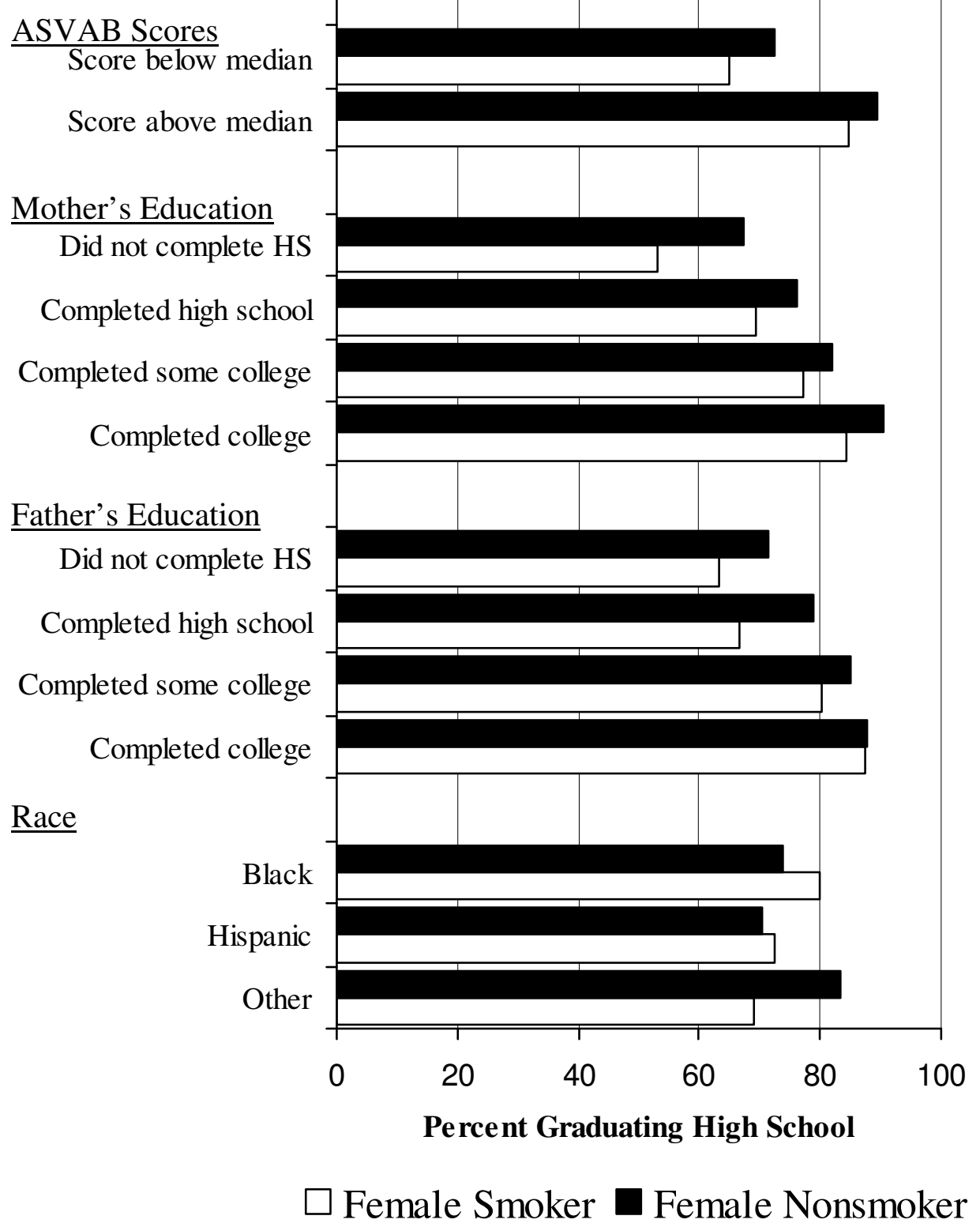




\section{Figure 3: Probability of College Matriculation for Male Graders}

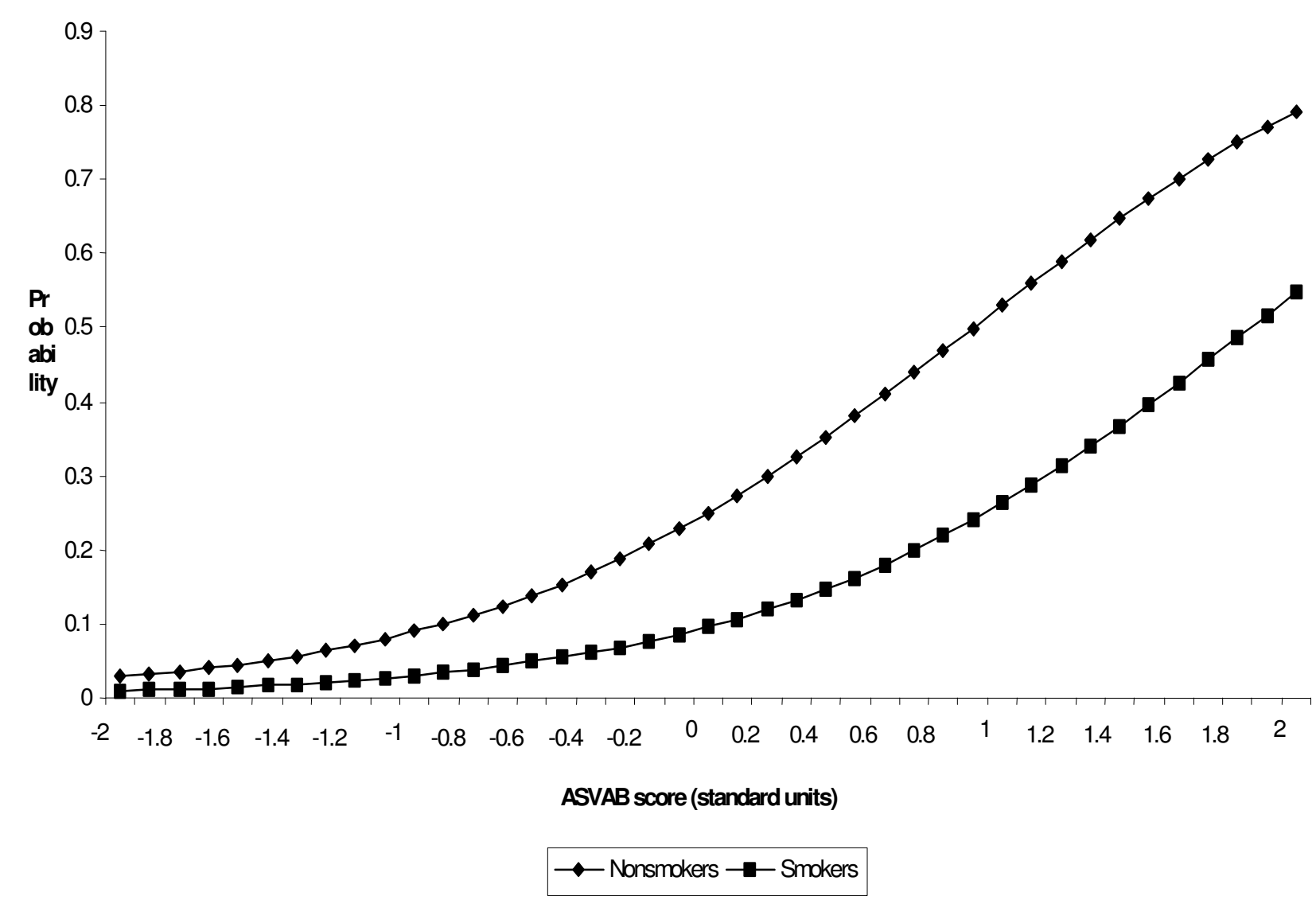

